ESTIMATES OF CONSUMPTIVE USE AND GROUND-WATER RETURN FIOW USING WATER BUDGETS IN PALO VERDE VALLEY, CALIFORNIA

By Sandra J. Owen-Joyce and Steven L. Kimsey

U.S. GEOLOGICAL SURVEY

Water-Resources Investigations Report 87-4070

Prepared in cooperation with the U.S. BUREAU OF RECLAMATION

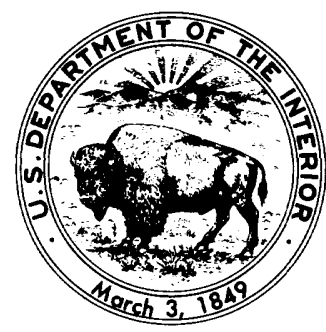




\author{
DEPARTMENT OF THE INTERIOR \\ DONALD PAUL HODEL, Secretary \\ U.S. GEOLOGICAL SURVEY \\ Dallas L. Peck, Director
}

For additional information write to:

District Chief

U.S. Geological Survey

Box FB-4 4

Federal Building

300 West Congress street

Tucson, Arizona 85701-1393
Copies of this report can be purchased from:

U.S. Geological survey

Books and Open-File

Reports section

Federal Center, Bldg. 810 Box 25425

Denver, CO 80225 
6. Diversions, surface-water return flows, and cultivated area in Palo Verde Valley, California,

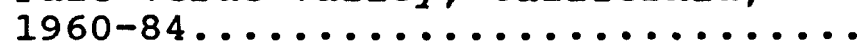

7. Daily mean flow in the colorado River at Palo Verde Dam, $1980-84 \ldots \ldots \ldots \ldots \ldots \ldots \ldots \ldots . \ldots . \ldots . \ldots 12$

8. Daily mean gage height of the Colorado River at Cibola cross Section No. 28, 1981-84......... 12

9. Annual precipitation at Blythe, California, 1917-84............

10-16. Maps showing:

10. Average water-table altitude in Palo Verde Valley, California,

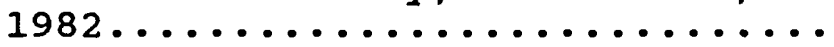

11. Average water-table altitude in Palo Verde Valley, California,

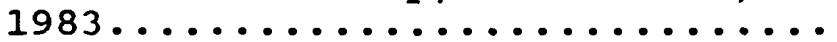

12. Average water-table altitude in Palo Verde Valley, California, 1984

13. Change in annual average groundwater levels in Palo Verde Valley, California, 1980-81...... 24

14. Change in annual average groundwater levels in Palo Verde Valley, California, 1981-82......

15. Change in annual average groundwater levels in Palo Verde Valley, California, 1982-83...... 28

16. Change in annual average groundwater levels in Palo Verde Valley, California, 1983-84...... 30

17. Graph showing:

17. Water levels in selected wells in Palo Verde Valley, California, 1980-84..................... 


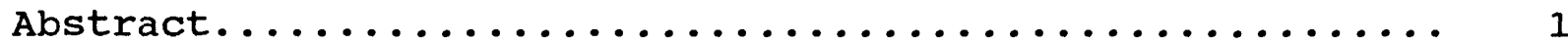

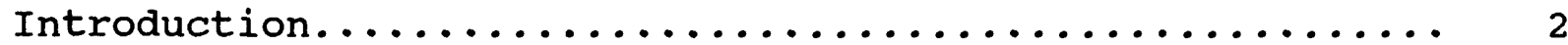

Physical setting......................... 3

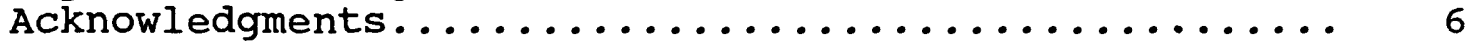

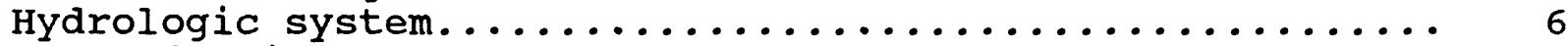

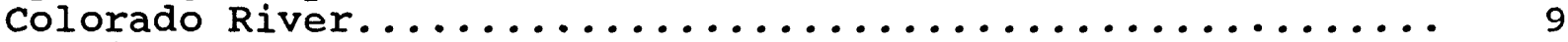

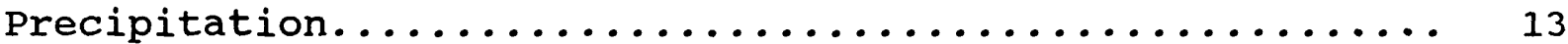

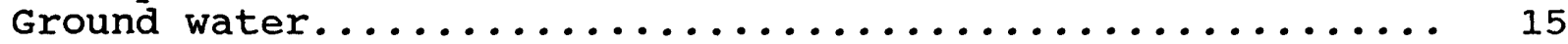

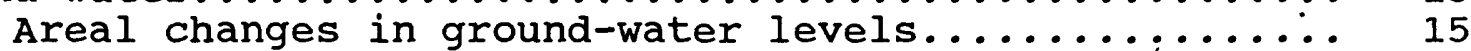

Change in storage........................ 33

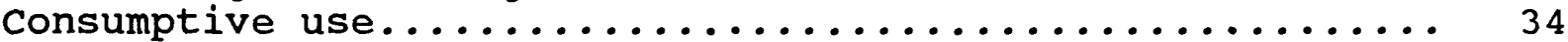

Ground-water return flow...................... 42

Diversions minus return flows.................... 45

Comparison of consumptive-use estimates.............. 46

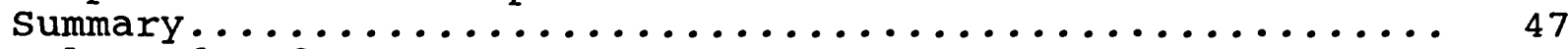

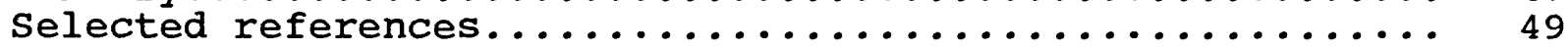

ILLUSTRATIONS

Page

Figures 1-2. Maps showing:

1. Area of report................ 3

2. Palo Verde Valley and location of streamflow-gaging stations and surface-water measurement sites.....................

3-5. Graphs showing:

3. Acreages by crop type, cultivated area, and total crops in Palo Verde Valley, California, $1980-84 \ldots \ldots \ldots \ldots \ldots \ldots \ldots \ldots \ldots . \ldots . \ldots$

4. Diversions, applied water, return flows, and total cropped area in Palo Verde Valley, California, 1981-84............

5. Flow in the Colorado River, $1960-85 \ldots \ldots \ldots \ldots \ldots \ldots \ldots \ldots . \ldots \ldots$ 
VI

Tables 8-11.-Continued Page

8. Estimates of consumptive use by vegetation in Palo Verde Valley, California,

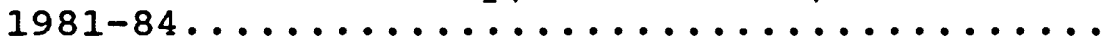

9. Evapotranspiration per unit area by vegetation in Palo Verde Valley, California, $1981-84 \ldots \ldots \ldots \ldots \ldots \ldots \ldots \ldots \ldots \ldots$

10. Primary variables used in the computation of consumptive use by vegetation and ground-water return flow in Palo Verde Valley, California, and sensitivity of results to a change in specified

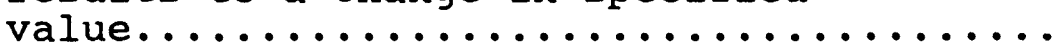

11. Water budgets for the area drained by the Colorado River in Palo Verde Valley,

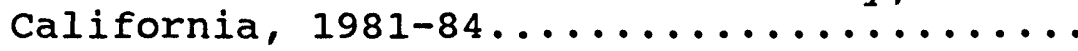


Figures 18-20. Graphs showing:

Page

18. Comparison of consumptive use by vegetation and evapotranspiration in Palo Verde Valley, California,

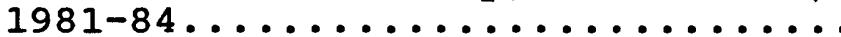

19. Comparison of consumptive use by vegetation and evapotranspiration per unit vegetated area in Palo Verde Valley, California, 1981-84.

20. Comparison of consumptive use by vegetation determined from a water budget and consumptive use of river water determined from diversions minus return flows in Palo Verde Valley, California, 1981-84............

TABLES

Page

Table 1. Estimates of surface-water return flows to the Colorado River in Palo Verde Valley, California, 1981-84................... 14

2. Annual precipitation for Blythe, California,

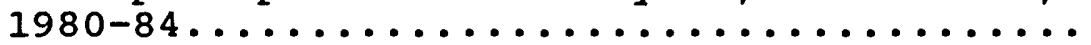

3. Annual water-level changes in Palo Verde Valley, California....................

4. Change in storage for Palo Verde Valley, California, 1981-84...................

5. Water budgets for the area drained by drainage ditches in Palo Verde Valley,

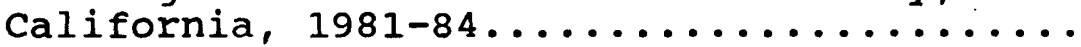

6. Estimates of surface-water diversions to irrigated land in Palo Verde Valley, California, $1981-84 \ldots . . \ldots \ldots . . .$.

7. Estimates of irrigation requirements and evapotranspiration by vegetation in Palo Verde Valley, California, 1981-84. 


\section{CONVERSION FACTORS}

For readers who prefer to use metric (International system) units rather than inch-pound units, the conversion factors for the terms used in this report are listed below:

\begin{tabular}{|c|c|c|}
\hline Multiply inch-pound unit & By & To obtain metric unit \\
\hline inch (in.) & 25.4 & millimeter $(\mathrm{mm})$ \\
\hline foot (ft) & 0.3048 & meter (m) \\
\hline mile (mi) & 1.609 & kilometer $(\mathrm{km})$ \\
\hline$\underset{\left(\mathrm{mi}^{2}\right)}{\text { square mile }}$ & 2.590 & $\underset{\left(\mathrm{km}^{2}\right)}{\text { square kilometer }}$ \\
\hline $\begin{array}{l}\text { foot per mile } \\
(\mathrm{m} / \mathrm{km})\end{array}$ & 0.1894 & $\begin{array}{l}\text { meter per kilometer } \\
(\mathrm{ft} / \mathrm{mi})\end{array}$ \\
\hline $\begin{array}{l}\text { foot squared per day } \\
\left(f t^{2} / d\right)\end{array}$ & 0.0929 & $\begin{array}{l}\text { meter squared per day } \\
\left(\mathrm{m}^{2} / \mathrm{d}\right)\end{array}$ \\
\hline $\begin{array}{l}\text { cubic foot per } \\
\text { second }\left(\mathrm{ft}^{3} / \mathrm{s}\right)\end{array}$ & 0.02832 & $\begin{array}{l}\text { cubic meter per } \\
\text { second }\left(\mathrm{m}^{3} / \mathrm{s}\right)\end{array}$ \\
\hline acre & 0.4047 & $\begin{array}{l}\text { square hectometer } \\
\left(\mathrm{hm}^{2}\right)\end{array}$ \\
\hline acre-foot (acre-ft) & 0.001233 & $\begin{array}{l}\text { cubic hectometer } \\
\left(\mathrm{hm}^{3}\right)\end{array}$ \\
\hline $\begin{array}{l}\text { acre-foot per year } \\
(\text { acre-ft/yr) }\end{array}$ & 0.001233 & $\begin{array}{l}\text { cubic hectometer per } \\
\text { year }\left(\mathrm{hm}^{3} / \mathrm{yr}\right)\end{array}$ \\
\hline $\begin{array}{l}\text { acre-foot per } \\
\text { square mile } \\
\left(\text { acre-ft } / \mathrm{mi}^{2}\right)\end{array}$ & 0.000476 & $\begin{array}{l}\text { cubic hectometer per } \\
\text { square kilometer } \\
\left(\mathrm{hm}^{3} / \mathrm{km}^{2}\right)\end{array}$ \\
\hline
\end{tabular}

Sea level: In this report "sea level" refers to the National Geodetic Vertical Datum of 1929 (NGVD of 1929) -A geodetic datum derived from a general adjustment of the first-order level nets of both the United States and Canada, formerly called "Mean sea Level of 1929." 


\title{
ESTIMATES OF CONSUMPTIVE USE AND GROUND-WATER RETURN FLOW USING WATER BUDGETS IN PALO VERDE VALLEY, CALIFORNIA
}

By

\author{
Sandra J. Owen-Joyce
}

and

Steven L. Kimsey

\begin{abstract}
Palo Verde Valley, California, is an agricultural area on the flood plain of the colorado River where irrigation water is diverted from the river and ground water is discharged to a network of drainage ditches and (or) the river. Consumptive use by vegetation and ground-water return flow were calculated using water budgets. Consumptive use by vegetation was 484,000 acre-feet in 1981, 453,600 acre-feet in 1982, 364,400 acre-feet in 1983, and 374,300 acre-feet in 1984. The consumptive-use estimates are most sensitive to two measured components of the water budget-the diversion at Palo Verde Dam and the discharge from drainage ditches to the river. Ground-water return flow was 31,700 acre-feet in $1981,24,000$ acre-feet in 1982, 2,500 acre-feet in 1983, and 7,900 acre-feet in 1984. The return-flow estimates are most sensitive to discharge from drainage ditches; various irrigation requirements and crop areas, particularly alfalfa; the diversion at Palo Verde Dam; and the estimate of consumptive use. During increasing flows in the river, the estimate of ground-water return flow is sensitive also to change in ground-water storage.
\end{abstract}

Change in ground-water storage was estimated to be $-5,700$ acre-feet in $1981,-12,600$ acre-feet in $1982,5,200$ acre-feet in 1983, and 11,600 acre-feet in 1984. Change in storage can be a significant component in the water budget used to estimate ground-water return flow but is negligible in the water budget used to estimate consumptive use. Change in storage was 1 to 3 percent of annual consumptive use. Change in storage for the area drained by the river ranged from 7 to 96 percent of annual ground-water return flow during the 4 years studied.

Consumptive use calculated as diversions minus return flows was consistently lower than consumptive use calculated in a water budget. Water-budget estimates of consumptive use account for variations in precipitation, tributary inflow, river stage, and ground-water storage. The calculations for diversions minus return flows do not account for these 
components, which can be large enough to affect the estimates of consumptive use.

\section{INTRODUCTION}

A decree by the U.S. Supreme court (1964) apportions the waters of the lower colorado River to the states of California, Arizona, and Nevada in terms of consumptive use, which is defined in the decree as "* * *diversions from the stream less such return flow thereto as is available for consumptive use* **." The decree requires that, for each diverter, the quantities of diversion and consumptive use be published annually.

Ground-water return flow is estimated in order to credit the states with total return flows from their diversions. The quantity of ground-water return flow is needed in order to estimate consumptive use as defined by the decree. Consumptive use of lower Colorado River water is estimated as diversions minus surface-water and ground-water return flows. Diversions and surface-water return flows are measured. Ground-water return flow cannot be measured but is estimated with a water budget for part of the area in Palo Verde Valley, California (Owen-Joyce, 1984) and Parker Valley, Arizona (Leake, 1984).

The method to estimate ground-water return flow requires that consumptive use by vegetation be estimated as the residual term in a ground-water budget for that part of the shallow alluvial aquifer drained by drainage ditches. consumptive use by vegetation is water lost through evapotranspiration and evaporation from bare-soil (nonvegetated) and open-water surfaces. Evapotranspiration refers to the loss of water from a land area through transpiration by vegetation and evaporation from the soil surface under the vegetation. Evapotranspiration calculated as the product of areas by vegetation types determined from Landsat digital-image analysis and predetermined water-use rates was tested as a method of approximating consumptive use along the lower colorado River (Raymond and Rezin, 1986). Evapotranspiration estimates were within \pm 3 percent of evapotranspiration calculated from crop maps (Raymond and Rezin, 1986, p. 30), which were within 12 to 17 percent of consumptive use by vegetation (Owen-Joyce, 1984 , p. 29; Leake, 1984, p. 25).

Palo Verde Valley, California (fig. 1), was chosen as a test area to compare estimates of consumptive use by vegetation and estimates of evapotranspiration calculated using the methods described above. The study was divided into two parts, each of which is documented in a separate report. This report describes the estimation of consumptive use by vegetation using water budgets. Estimates of evapotranspiration using Landsat digital-image data and the comparison of evapotranspiration to consumptive use are found in Raymond and owen-Joyce (1987). 


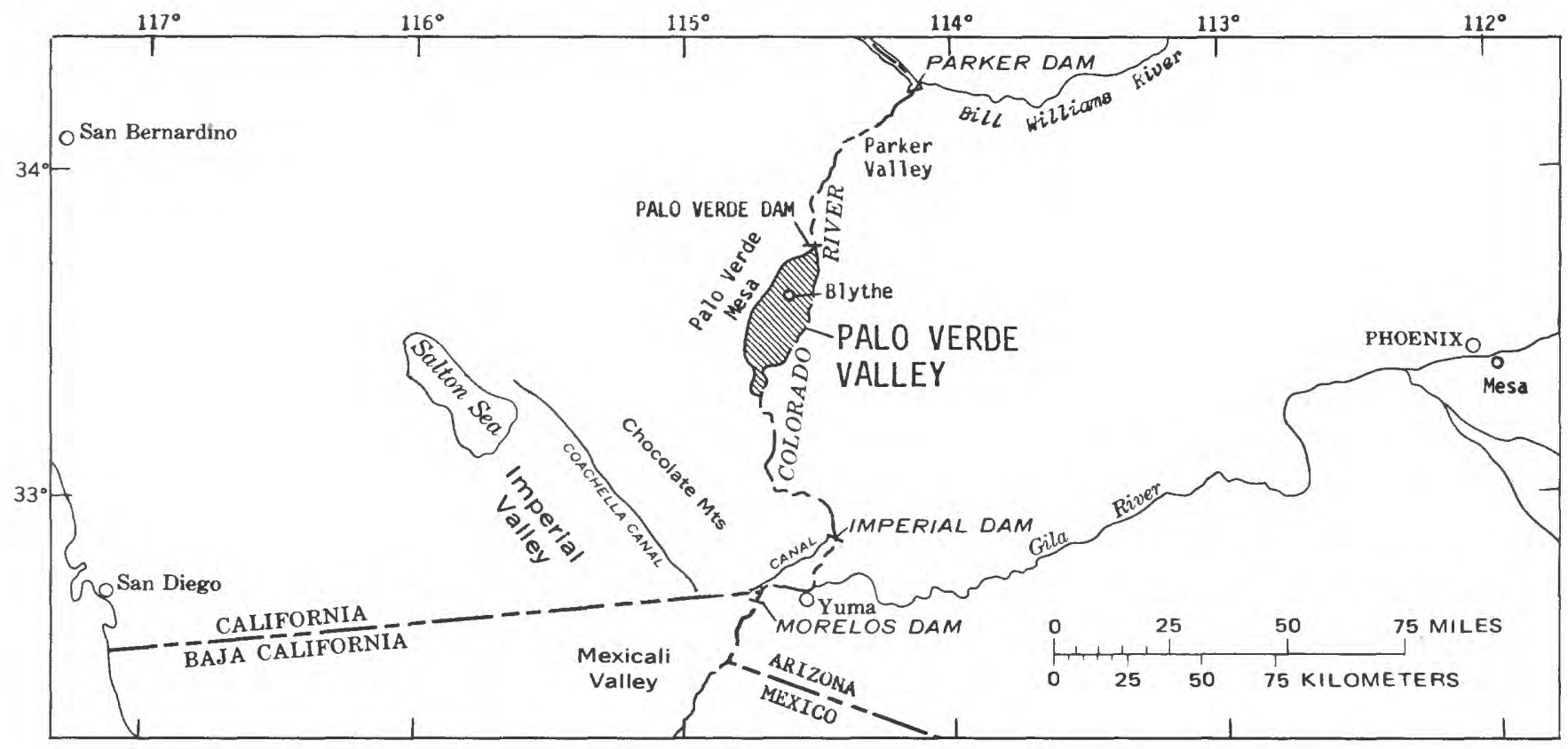

Figure 1.--Area of report (shaded).

This report describes the calculation of consumptive use by vegetation for 1981, 1982, 1983, and 1984. Multiple years of data allowed for the testing of the assumption made in the methodology report (Owen-Joyce, 1984) that change in groundwater storage was small and therefore negligible in the waterbudget calculations. This report includes a brief description of the hydrologic system, estimates of consumptive use by vegetation determined by using water budgets, estimates of change in ground-water storage, estimates of ground-water return flow, estimates of consumptive use calculated as diversions minus return flows, and a comparison of estimates of consumptive use by vegetation to estimates of consumptive use as diversions minus return flows.

\section{Physical setting}

Palo Verde Valley contains about $175 \mathrm{mi}^{2}$ of flood plain along the Colorado River in eastern Riverside and Imperial counties, California, adjacent to the boundary with Arizona (fig. 1). Palo Verde Valley is bounded on the west by the edge of the flood plain and on the east by the colorado River. The main population center is Blythe (fig. 2). Most of the flood plain is used for agriculture. About 93,000 acres are cultivated. Many fields are double- or triple-cropped annually. 


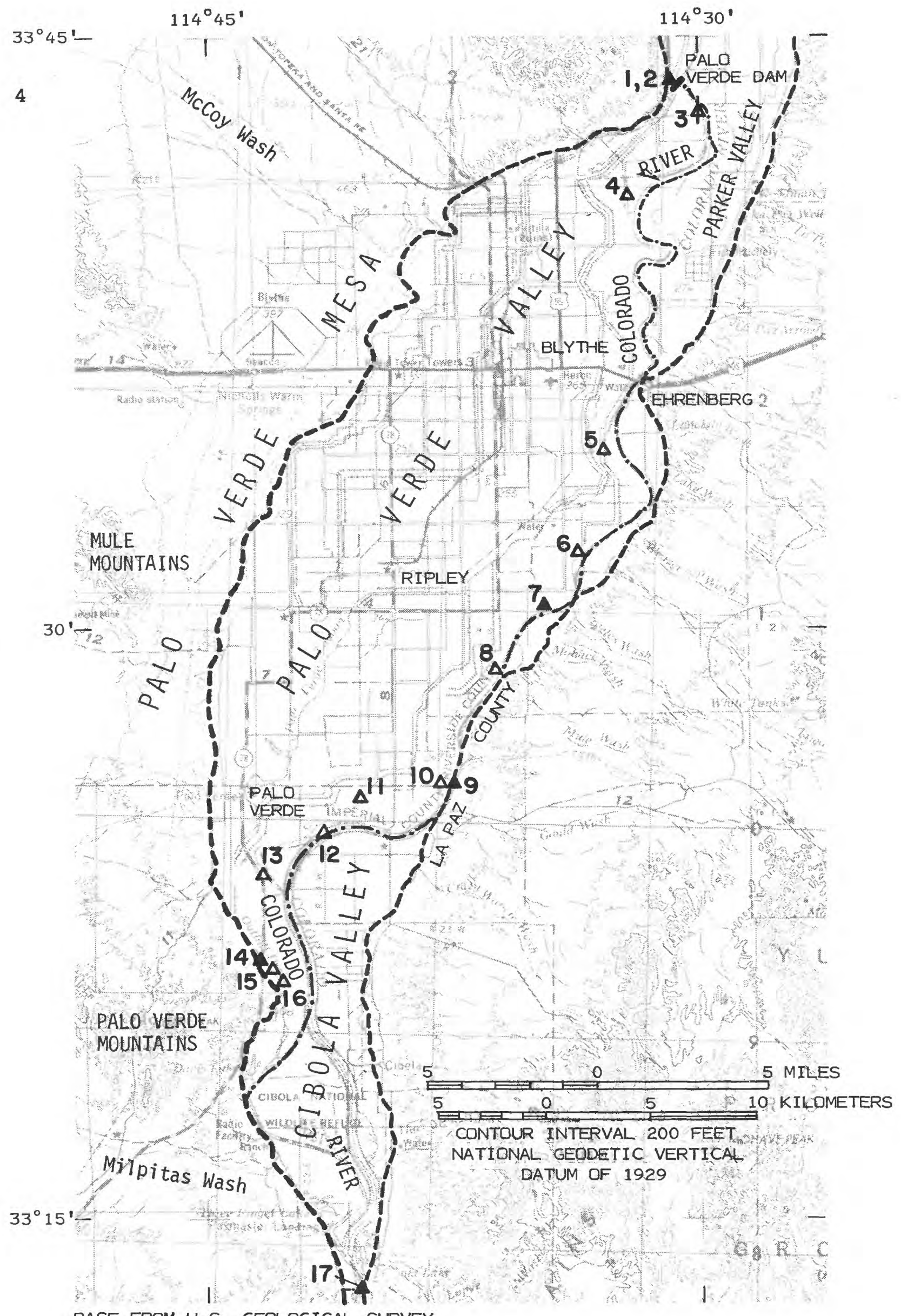

BASE FROM U.S. GEOLOGICAL SURVEY

$1: 250,000$ SALTON SEA, 1959-69

Figure 2.--Palo Verde Valley and location of streamflow-gaging stations and surface-water measurement sites. 
$\Delta_{2}$

CONTINUOUS-RECORD STREAMFLOW-GAGING STATION-Number, 2 , corresponds to station names listed below

$\Delta_{4}$

MEASUREMENT SITE-Number, 4, corresponds to site names listed below

43

DISCONTINUED STREAMFLOW-GAGING STATION-Number, 3 , corresponds to station names listed below

COLORADO RIVER FLOOD-PLAIN BOUNDARY

BOUNDARY OF PALO VERDE VALLEY WHERE THE FLOOD-PLAIN AQUIFER IS CONTINUOUS

Index of gaging stations and measurement sites

1. Palo Verde Canal near Blythe.

2. Colorado River at Palo Verde Dam.

3. Colorado River below Palo Verde Dam.

4. 01 ive Lake drain near Blythe.

5. F-canal spill near Blythe.

6. D-10-11-2 spil1 near Blythe.

7. D-10-11-5 spill near Blythe.

8. D-23 spill near Blythe.

9. Colorado River at Taylor Ferry near Blythe.

10. D-23-1 spill near Blythe.

11. C-canal spill near Blythe.

12. Colorado River at Cibola Cross Section No. 28.

13. C-28 upper spill near B1ythe.

14. Palo Verde Outfall drain near Palo Verde.

15. Anderson drain near Palo Verde.

16. C-28 lower spill near B1ythe.

17. Colorado River below Cibola Valley. 
All crops are irrigated because the mean annual precipitation of 3.91 in. (California Department of Water Resources, 1981 , p. 671) is insufficient for growing crops. About 6,900 acres are covered with phreatophytes.

River stage, the mixture of crops grown, and diversions to Palo Verde Valley changed from 1980 to 1984 . Flow in the river exceeded downstream requirements for part of 1980 and for 1983 and 1984. The largest change in the crop mixture occurred during 1983 (fig. 3) when the Federal government instituted the PIK (Payment-In-Kind) program in which cotton growers were subsidized for not planting as much as half of their usual cotton acreage. About 11,000 acres of land were removed from crop production in 1983 (fig. 3) because of the PIK program (Palo Verde Irrigation District, written commun., 1984). Many of the fields left fallow were irrigated and cultivated to preserve soil structure. Volunteer vegetation grew in response to the irrigation and cultivation. In 1984 some of the fields remained fallow but most were planted with crops. Diversions to the valley and applied water varied from year to year and followed the same trend as the total cropped area (fig. 4).

\section{Acknowledgments}

Roger E. Henning and Jerry Wolford, Jr., of Palo Verde Irrigation District, provided irrigation and agricultural data. Hydrologic and crop data were collected by Palo Verde Irrigation District (PVID) and included monthly and annual average water levels in wells, monthly stage measurements in the drainage ditches, spillage from canals, flow in olive lake and Anderson drains, and crop type and acreage for each field in the valley. These data were used to calculate water budgets and change in ground-water storage. H. C. Millsaps of the U.S. Soil Conservation service provided evapotranspiration values for alfalfa, cotton, and grains determined from soil-moisture studies in Parker Valley. D. M. Clay, D. J. Bivens, and G. R. Scarbrough of the U.S. Geological Survey collected and processed many of the water-level data used for this study.

\section{HYDROLOGIC SYSTEM}

In Palo Verde Valley the hydrologic system includes the highly regulated Colorado River and a shallow alluvial aquifer that underlies the flood plain. River water is diverted into a system of canals for distribution to fields on the flood plain, and ground water discharges to a network of drainage ditches and the river. The drainage ditches lower the water table beneath cropland and maintain it at sufficient depths to reduce waterlogging and damage to crops. The colorado River and the drainage ditches are in hydraulic connection with ground water in the shallow alluvial aquifer. Depth to water in the 


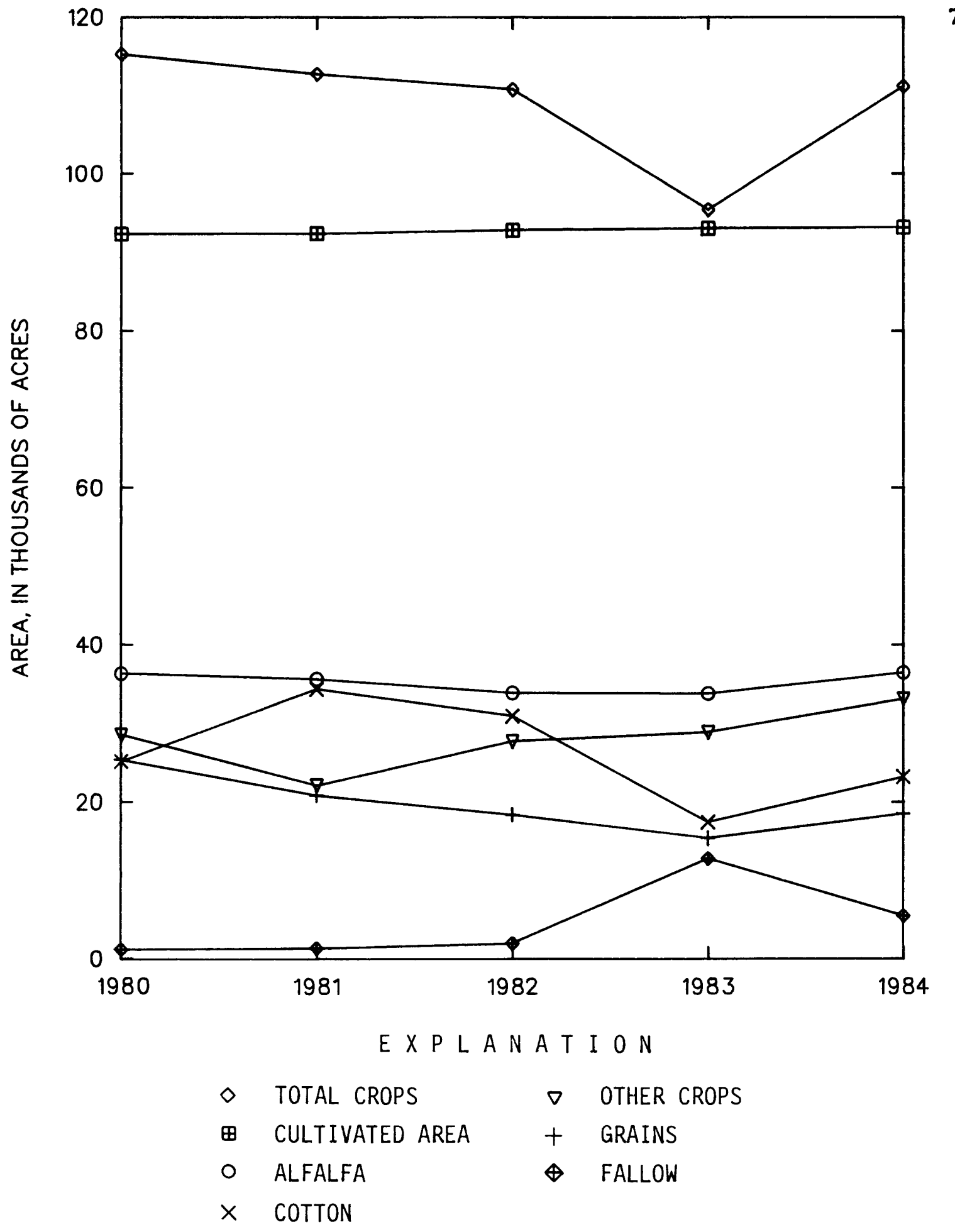

Figure 3.--Acreages by crop type, cultivated area, and total crops in Palo Verde Valley, California, 1980-84. 


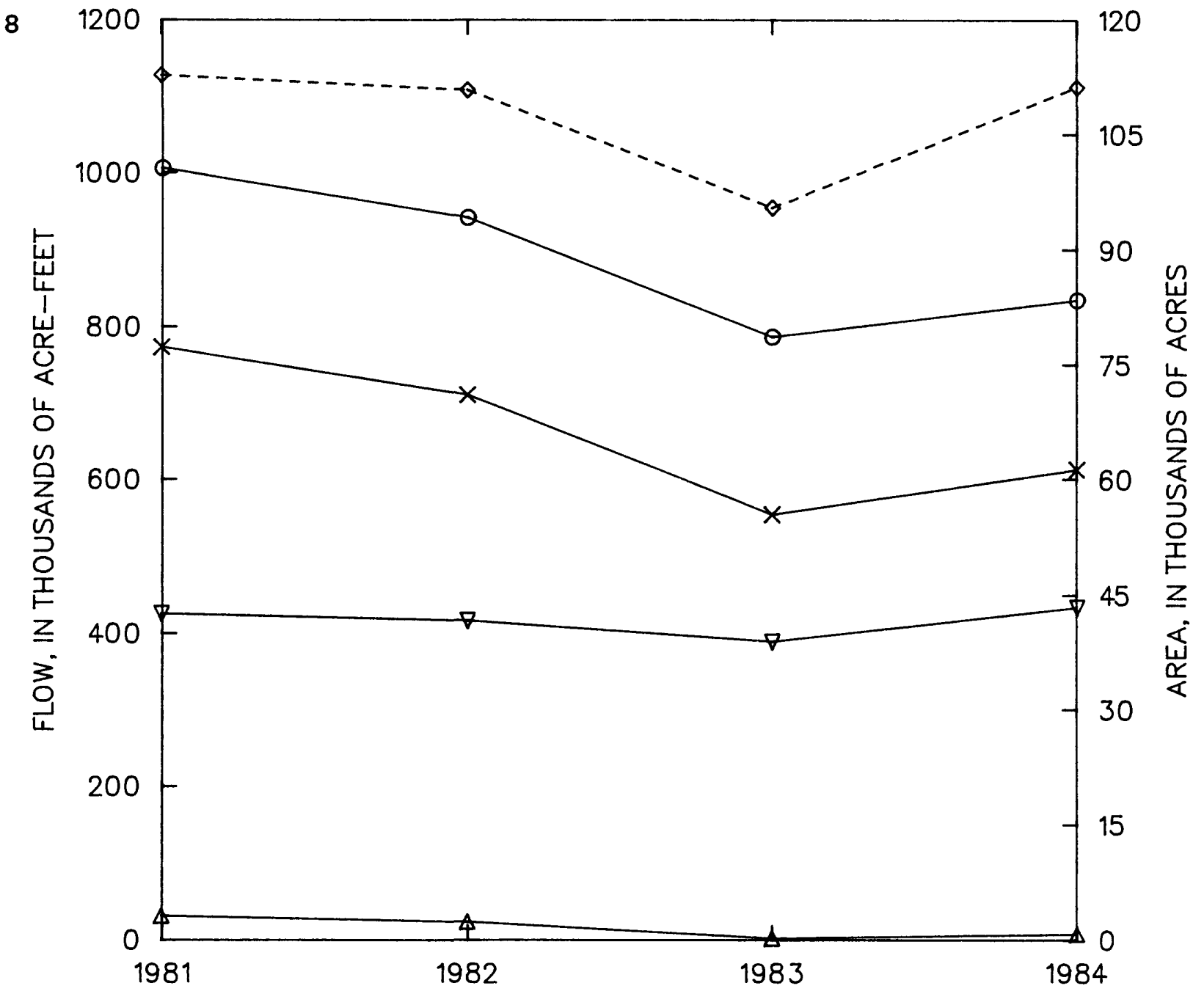

EXPLANATION

AREA

$\diamond-\cdots-\infty$ Total crops

FLOW

○ Diverted irrigation water

$\longleftarrow \quad \times$ Applied irrigation water

$\nabla$ Surface-water return flow

$\triangle$ Ground-water return flow

Figure 4.--Diversions, applied water, return flows, and total cropped area in Palo Verde Valley, California, 1981-84. 
aquifer is less than $25 \mathrm{ft}$. When releases from the reservoirs satisfy downstream water requirements, most reaches of the river adjacent to the irrigated areas gain water from the aquifer. Some reaches of the river adjacent to areas of phreatophytes lose water to the aquifer. When the annual average river stage rises, some of the gaining reaches of the river can become losing reaches, particularly where the ground-water divide is close to the river.

When flow in the river is regulated to meet downstream water requirements, drainage ditches and the application of irrigation water to fields control saturated thickness in the aquifer and direction of ground-water movement through the aquifer. Water is diverted from the river into canals from which some water spills back to the river or into drainage ditches (irrigation district regulatory waste), some enters the aquifer because of canal seepage, some evaporates, and the rest is applied to fields. Applied water is consumptively used by crops or recharges the aquifer through deep percolation. Deep percolation of irrigation water causes mounding of the water table under the fields and creates shallow ground-water divides between drainage ditches and between the easternmost drainage ditch and the river. In the area drained by drainage ditches, ground water discharges into drainage ditches and flows to the Colorado River as surface-water return flow. In the area drained by the river, ground water discharges to the river as ground-water return flow. Some ground water is intercepted and consumed by phreatophytes mainly saltcedar, arrowweed, and mesquite -and some is pumped for municipal and domestic use. In addition to applied irrigation water, other sources of recharge to the aquifer are ground-water inflow from areas that border the flood plain and infiltration of runoff from tributary areas. Along some reaches, the river loses water to the aquifer through seepage and ground water moves away from the river. In places, ground water flows out of the flood plain into bordering areas. The hydrologic system is described in detail by owen-Joyce (1984).

\section{COLORADO RIVER}

Flow in the colorado River is controlled by a series of dams upstream from Palo Verde Valley. Releases from Parker Dam, which is about $58 \mathrm{mi}$ upstream from the north end of Palo Verde Valley (fig. 1), satisfy most downstream water and flood-control requirements. Annual releases from Parker Dam from 1960 to 1984 ranged from 6.3 to $20.5 \mathrm{million}$ acre-ft (fig. 5). Flows in 1980, 1983, and 1984 exceeded downstream requirements because water was released for flood control. Palo Verde Dam is a diversion structure for irrigation water (fig. 2). The annual diversion of water at Palo Verde Dam ranged from 775,300 to $1,006,000$ acre-ft between 1960 and 1984 (fig. 6). From 1960 to 1984, annual flow in the colorado River below Palo Verde Dam ranged from 5.1 to $18.3 \mathrm{million}$ acre-ft 


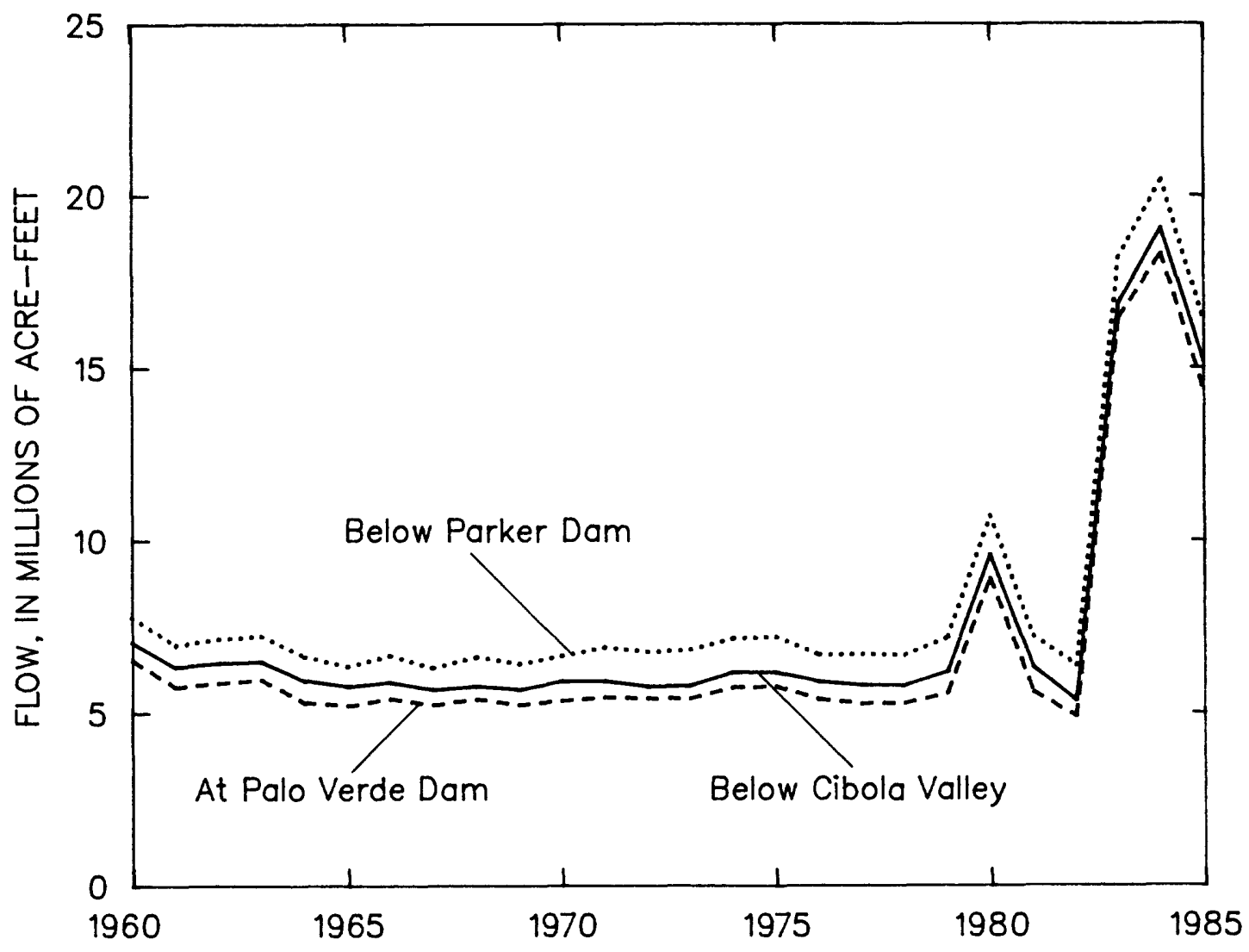

Figure 5.--Flow in the Colorado River, 1960-85.

(fig. 5). Annual flow in the Colorado River below Cibola Valley (fig. 2, site 17) ranged from 5.5 to 19.1 million acre-ft from 1960 to 1984 (fig. 5). The increase in flow between the gages is from surface-water and ground-water return flows.

Flow in the colorado River varies daily, seasonally, yearly, and from place to place along the river. Diversions, evapotranspiration, spillage from canals, return flows to the river, and releases of water for irrigation and power generation all contribute to daily fluctuations in flow. Seasonal variations occur because releases from Parker Dam are highest in summer when the irrigation needs are greatest as shown in 1981 and 1982 (fig. 7). During the latter half of 1980 and in 1983 and 1984, flood-control releases dominated and the seasonal variations did not exist.

Changes in flow in the Colorado River correlate with changes in river stage. Changes in river stage cause fluctuations in ground-water levels beneath the flood plain and in the amount of ground water in storage because the river is hydraulically connected to ground water in the alluvium. River stage was from 5 to $10 \mathrm{ft}$ higher in 1983 and 1984 than it was in 1982 (fig. 8). 

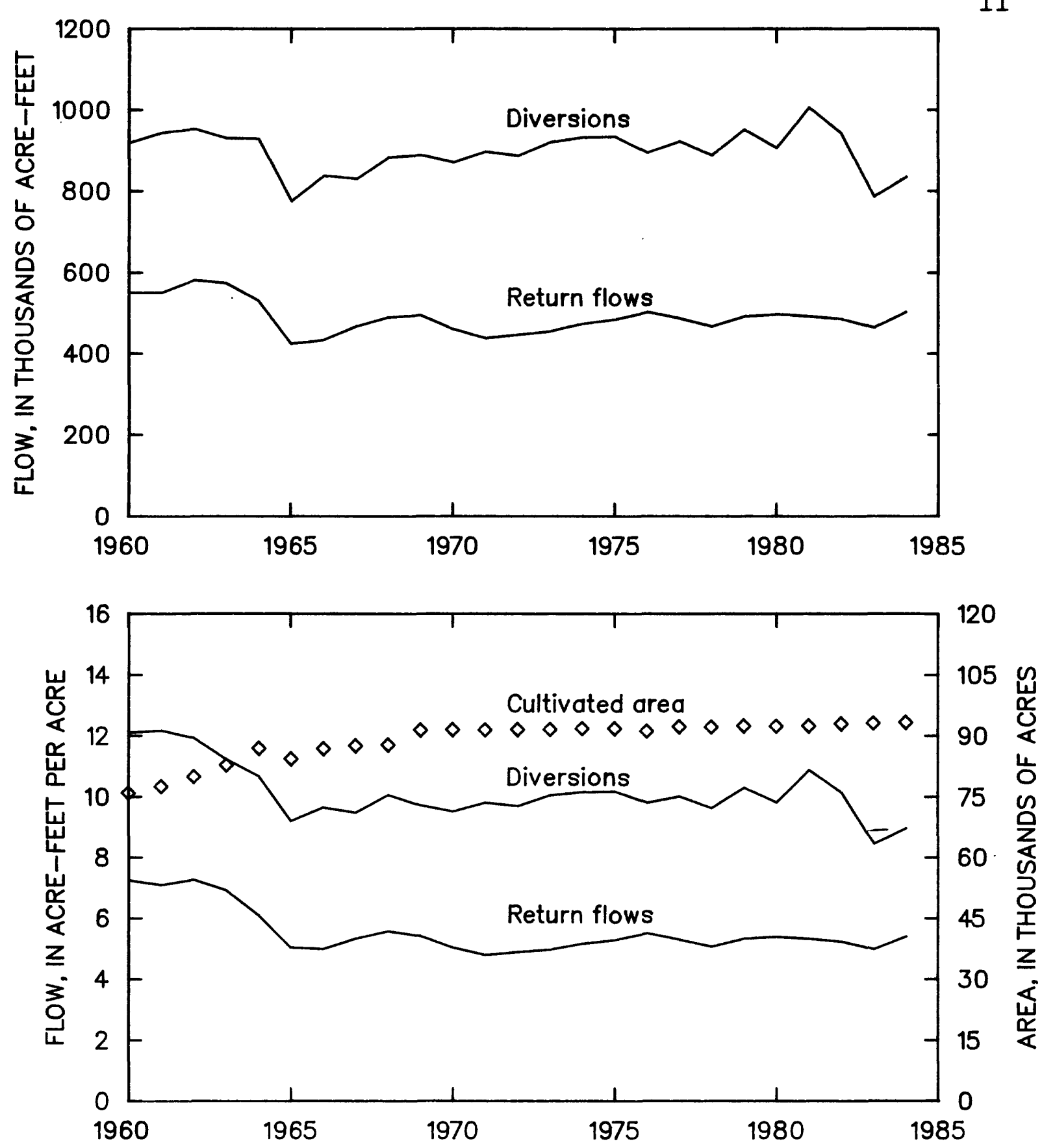

Figure 6.--Diversions, surface-water return flows, and cultivated area in Palo Verde Valley, California, 1960-84. 


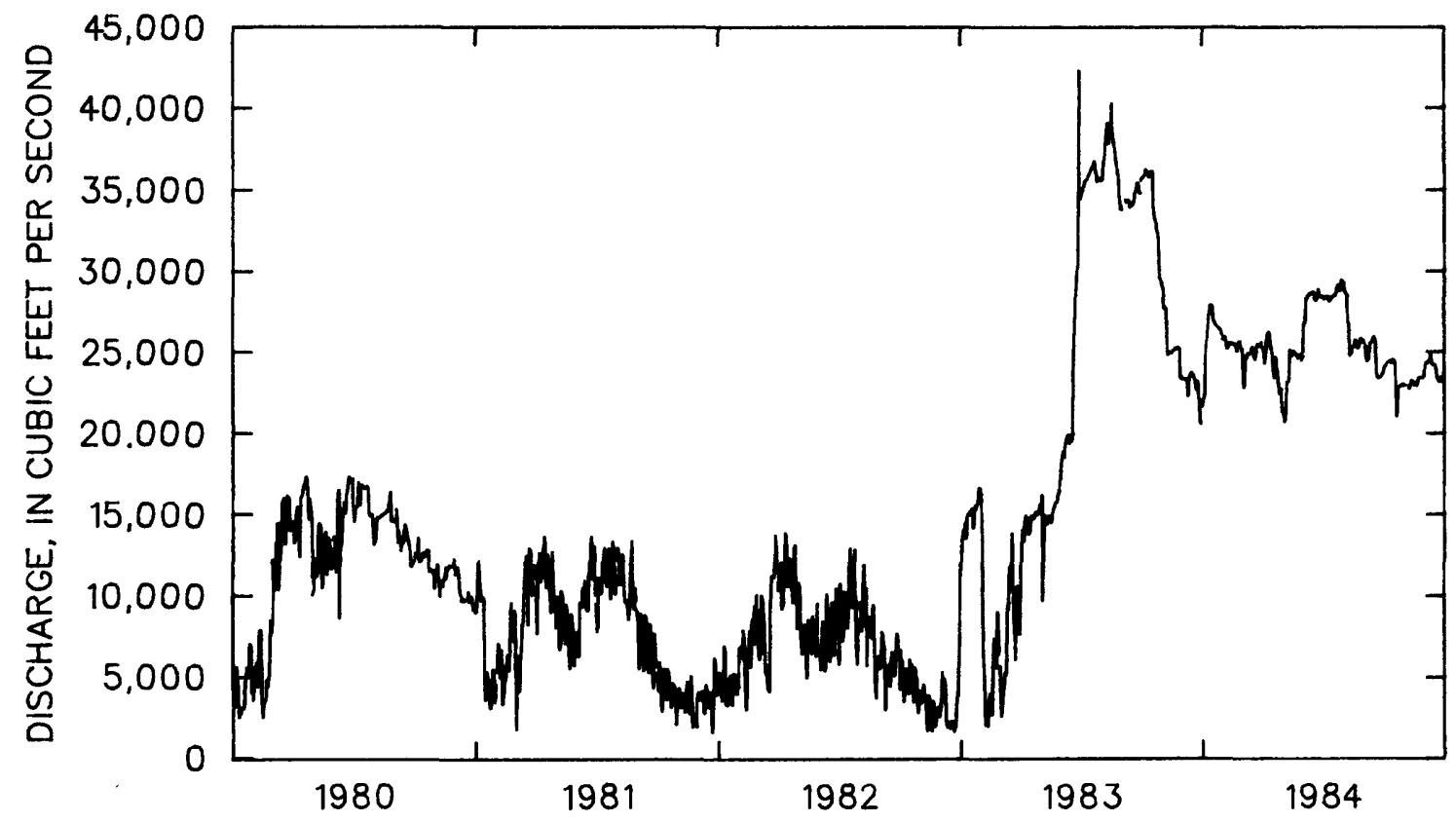

Figure 7.--Daily mean flow in the Colorado River at Palo Verde Dam, 1980-84.

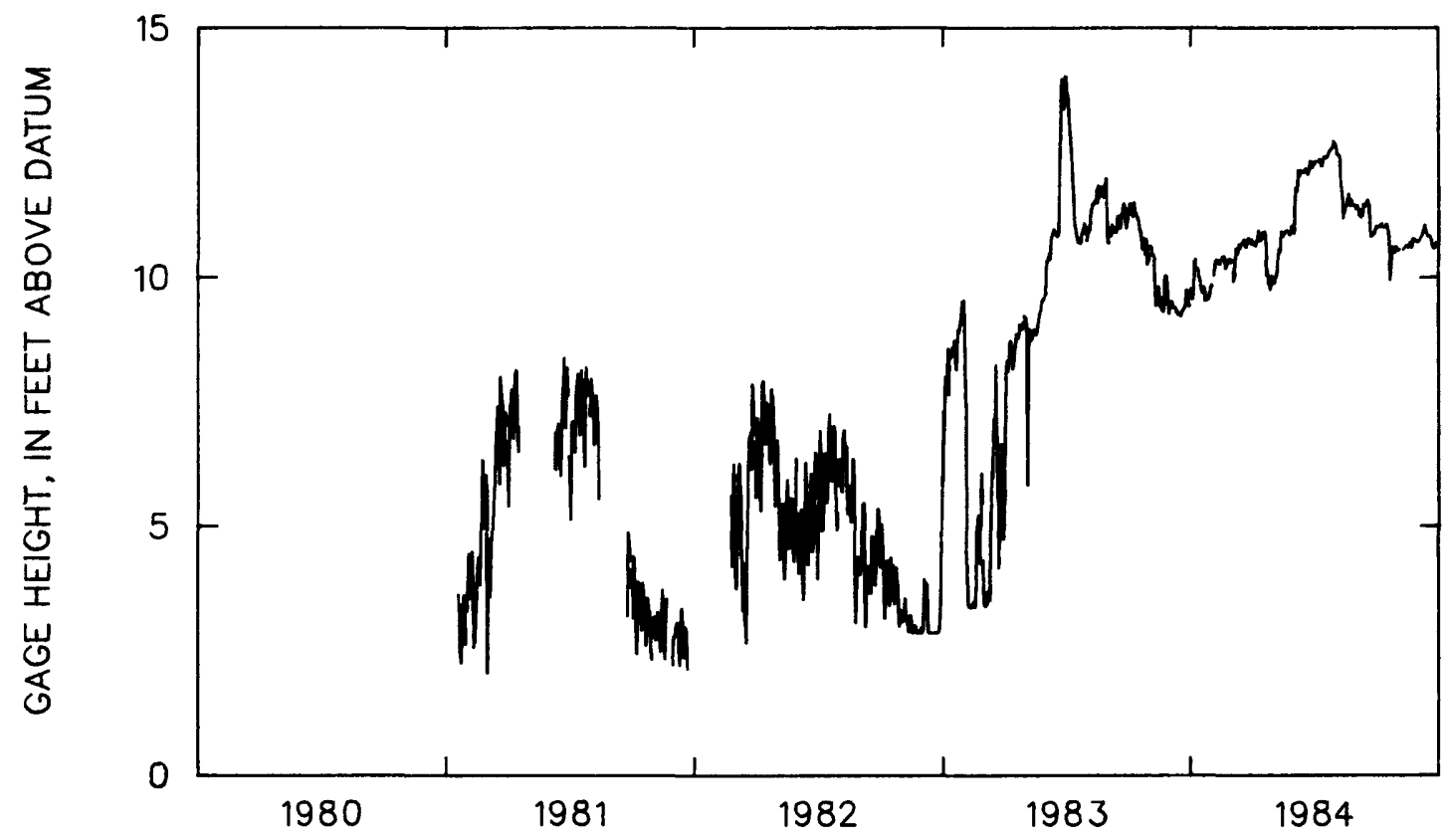

Figure 8.--Daily mean gage height of the Colorado River at Cibola Cross Section No. 28, 1981-84. 
Diverted water that returns to the river as surface water was computed at eight spillways and three drainage ditches (table 1). Surface-water return flows include water that spills from canals, laterals, and wasteways and ground water that drains into about $152 \mathrm{mi}$ of open-channel drainage ditches. As of June 1984, the gage on Anderson drain had been removed and the drain filled in (fig. 2, site 15).

\section{PRECIPITATION}

Precipitation provides a small quantity of water, some of which is available for consumptive use by vegetation. Precipitation is considered to be a source of recharge to the aquifer when the mean annual precipitation exceeds 8 in. (Metzger and Loeltz, 1973, p. 35). Annual precipitation at Blythe, California, ranged from 0.48 to 8.74 in. between 1917 and 1984 ( $f$ ig. 9), and mean annual precipitation was 3.88 in. About one-third of the precipitation occurs from May to September.

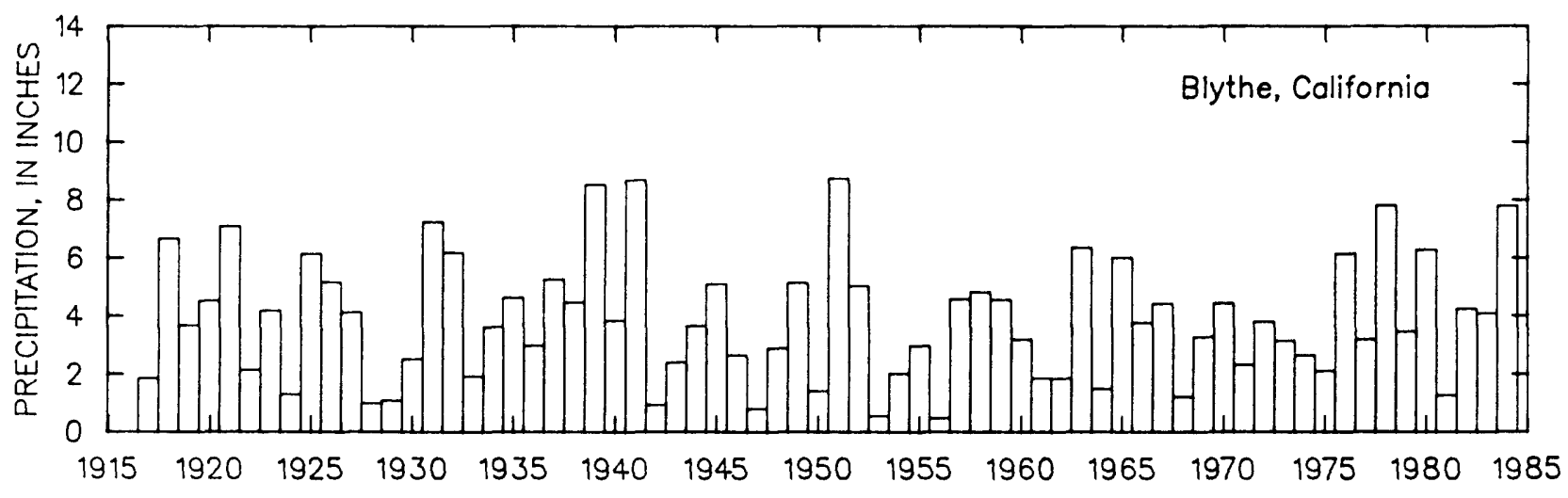

Figure 9.--Annual precipitation at Blythe, California, 1917-84.

Effective precipitation was used as a measure of the quantity of precipitation available for consumptive use by vegetation for input into the water budgets. Effective precipitation was calculated by multiplying the sum of the cropped cultivated area and area of phreatophytes each year by the annual effective precipitation ( $t a b l e$ 2). Annual effective-precipitation estimates were made by summing, rainfall that was in excess of 0.25 in. per storm (U.S. Bureau of Reclamation, Lower Colorado River Region, Yuma Project office, oral commun., 1986) to determine the amount of precipitation available to vegetation that could affect the consumptive use of Colorado River water. Annual effective precipitation from 1980 to 1984 (table 2) was computed from weather records for Blythe, California (National Climate Data Center, 1980-84). 
Table 1.--Estimates of surface-water return flows to the Colorado River in Palo Verde Valley, California,

1981-84, in acre-feet per year

\begin{tabular}{ccrrrr}
\hline $\begin{array}{c}\text { Site } \\
\text { number }\end{array}$ & Site number & 1981 & 1982 & 1983 & 1984 \\
\hline 5 & F-canal spill & 9,880 & 10,960 & 13,330 & 12,240 \\
6 & D-10-11-2 spill & 946 & 822 & 1,860 & 1,370 \\
7 & D-10-11-5 spill & 6,130 & 7,020 & 6,490 & 5,510 \\
8 & D-23 spill & 10,020 & 10,530 & 14,530 & 14,620 \\
10 & D-23-1 spill & 3,290 & 2,840 & 3,350 & 6,090 \\
11 & C-canal spill & 25,910 & 24,050 & 24,270 & 19,070 \\
13 & C-28 upper spill & 1,900 & 1,990 & 537 & 187 \\
16 & C-28 lower spill & 7,480 & 9,940 & 10,160 & 9,900
\end{tabular}

Subtotal of surface-water return flows that spill

from canals (rounded)

\begin{tabular}{|c|c|c|c|}
\hline 65,600 & 68,200 & 74,500 & 69,000 \\
\hline 6,370 & 8,810 & 7,510 & 7,710 \\
\hline 419,400 & 407,900 & 381,500 & 426,200 \\
\hline 110 & 274 & 362 & 152 \\
\hline
\end{tabular}

Subtotal of surface-water

return flows from the

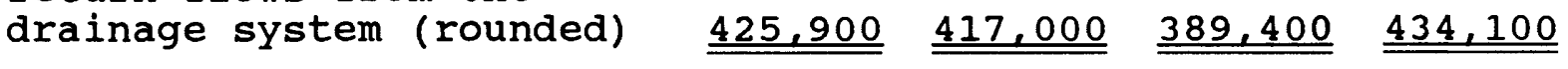

Total surface-water

return flows (rounded) $491,500 \quad 485,200 \quad 463,900 \quad 503,100$

${ }^{1}$ Site number corresponds to locations shown on figure 2.

${ }^{2}$ Located in the area drained by the river.

${ }^{3}$ Located in the area drained by drainage ditches. 
Table 2.--Annual precipitation for Blythe, California, 1980-84, in inches

Precipitation

\begin{tabular}{lcc}
\cline { 2 - 3 } Year & Effective & Total \\
\hline 1980 & 3.66 & 5.61 \\
1981 & 0.41 & 1.24 \\
1982 & 2.15 & 4.24 \\
1983 & 1.51 & 4.08 \\
1984 & 5.08 & 7.76
\end{tabular}

\section{GROUND WATER}

Palo Verde Valley was divided into two ground-water drainage areas using contours of annual average water-table altitude to determine the location of the ground-water divide between the river and the easternmost drainage ditch (Owen-Joyce, 1984, p. 19). Ground water east of the divide drains to the river, and that west of the divide drains to the drainage ditches. Annual average water-table altitudes were determined by averaging monthly water levels in wells, monthly stage measurements in the drainage ditches, and monthly water levels in piezometers installed along the river.

Water-table contours indicate that the ground-water divide moves from year to year and that the location of the gaining and losing reaches varies along the river. In 1981, the river gained ground-water inflow from Palo Verde Valley except along a $0.6-\mathrm{mile}$ losing reach north of Ehrenberg (Owen-Joyce, 1984, fig. 9). In 1982, the reaches adjacent to the valley gained water from the aquifer (fig. 10). In 1983, most of the river was losing water to the aquifer except at the north end of the valley and for a short reach south of Ehrenberg (fig. 11). In 1984, most of the river north of Cibola valley gained water from the aquifer except at the bend in the river south of olive Lake drain. The reach of the river adjacent to cibola valley lost water to the aquifer (fig. 12).

\section{Areal Changes in Ground-Water Levels}

Ground-water levels vary from year to year and from place to place in Palo Verde Valley. The most significant changes occur along the river. Changes in annual average water levels were determined by subtracting the annual average 


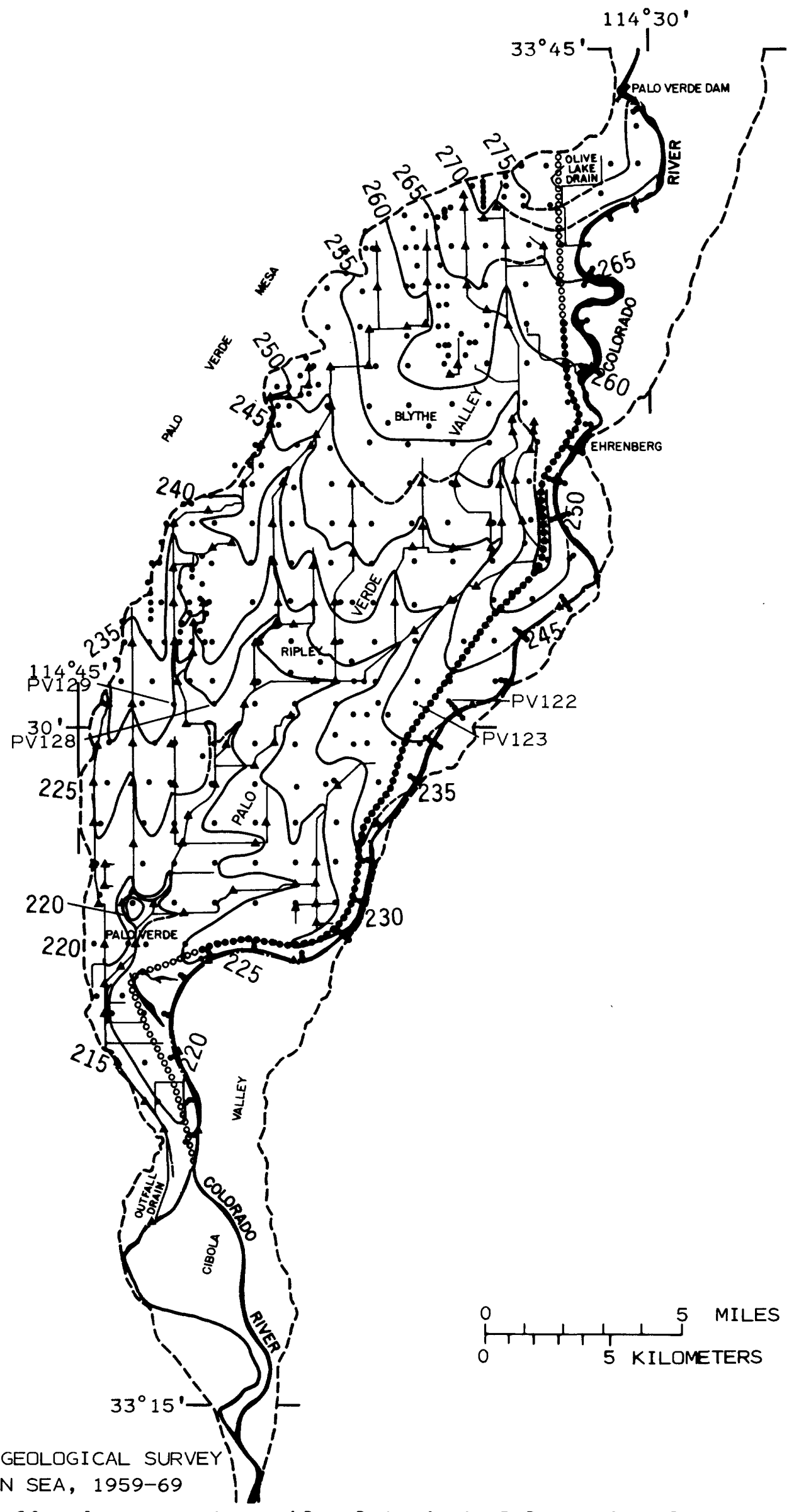

BASE FROM U.S. GEOLOGICAL SURVEY $1: 250,000$ SALTON SEA, 1959-69

Figure 10.--Average water-table altitude in Palo Verde Valley, California, 1982. 
WATER-TABLE CONTOUR-Shows average altitude of water table, 1982. Dashed where approximately located. Contour interval 5 feet. Datum is sea level

PV $128^{\circ}$ SHALLOW OBSERVATION WELL OR PIEZOMETER-Number, PV128, is a well number that corresponds to the hydrographs on figure 17

- STAFF gAGE

DRAINAGE DITCH

GROUND-WATER DIVIDE BETWEEN THE COLORADO RIVER AND DRAINAGE DITCHES - Open symbol where approximately located

COLORADO RIVER FLOOD-PLAIN BOUNDARY

BOUNDARY OF PALO VERDE VALLEY WHERE THE FLOOD-PLAIN AQUIFER IS CONTINUOUS 


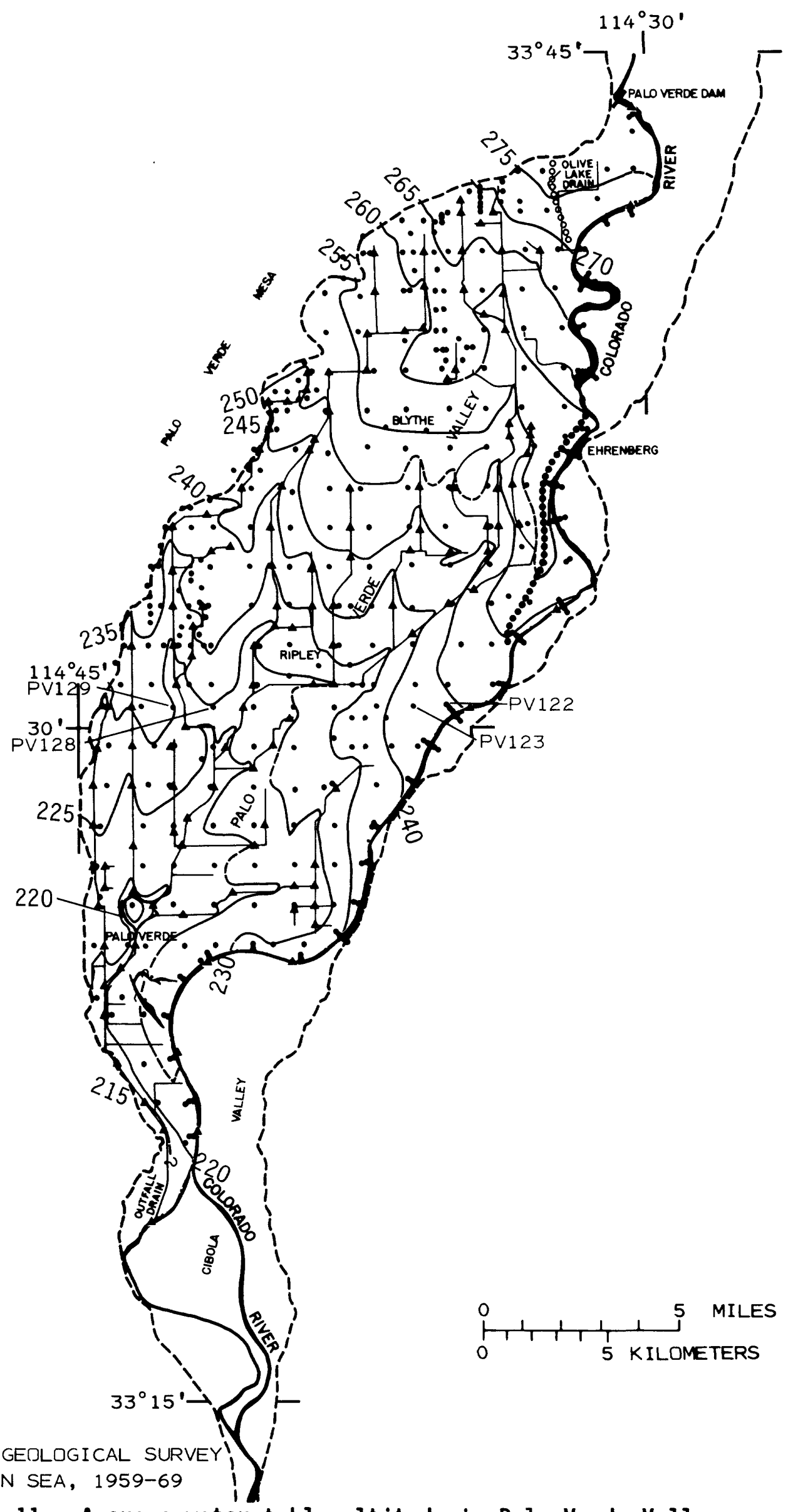

BASE FROM U.S. GEOLOGICAL SURVEY $1: 250,000$ SALTON SEA, 1959-69

Figure 11.--Average water-table altitude in Palo Verde Valley, California, 1983. 
EXPLANATION

225 - - ? - WATER-TABLE CONTOUR-Shows average altitude of water table, 1983. Dashed where approximately located, queried where uncertain. Contour interval 5 feet. Datum is sea level

PV128 SHALLOW OBSERVATION WELL OR PIEZOMETER-Number, PV128, is a well number that corresponds to the hydrographs on figure 17

- STAFF GAGE

DRAINAGE DITCH

GROUND-WATER DIVIDE BETWEEN THE COLORADO RIVER AND DRAINAGE DITCHES - Open symbol where approximately located

COLORADO RIVER FLOOD-PLAIN BOUNDARY

BOUNDARY OF PALO VERDE VALLEY WHERE THE FLOOD-PLAIN AQUIFER IS CONTINUOUS 


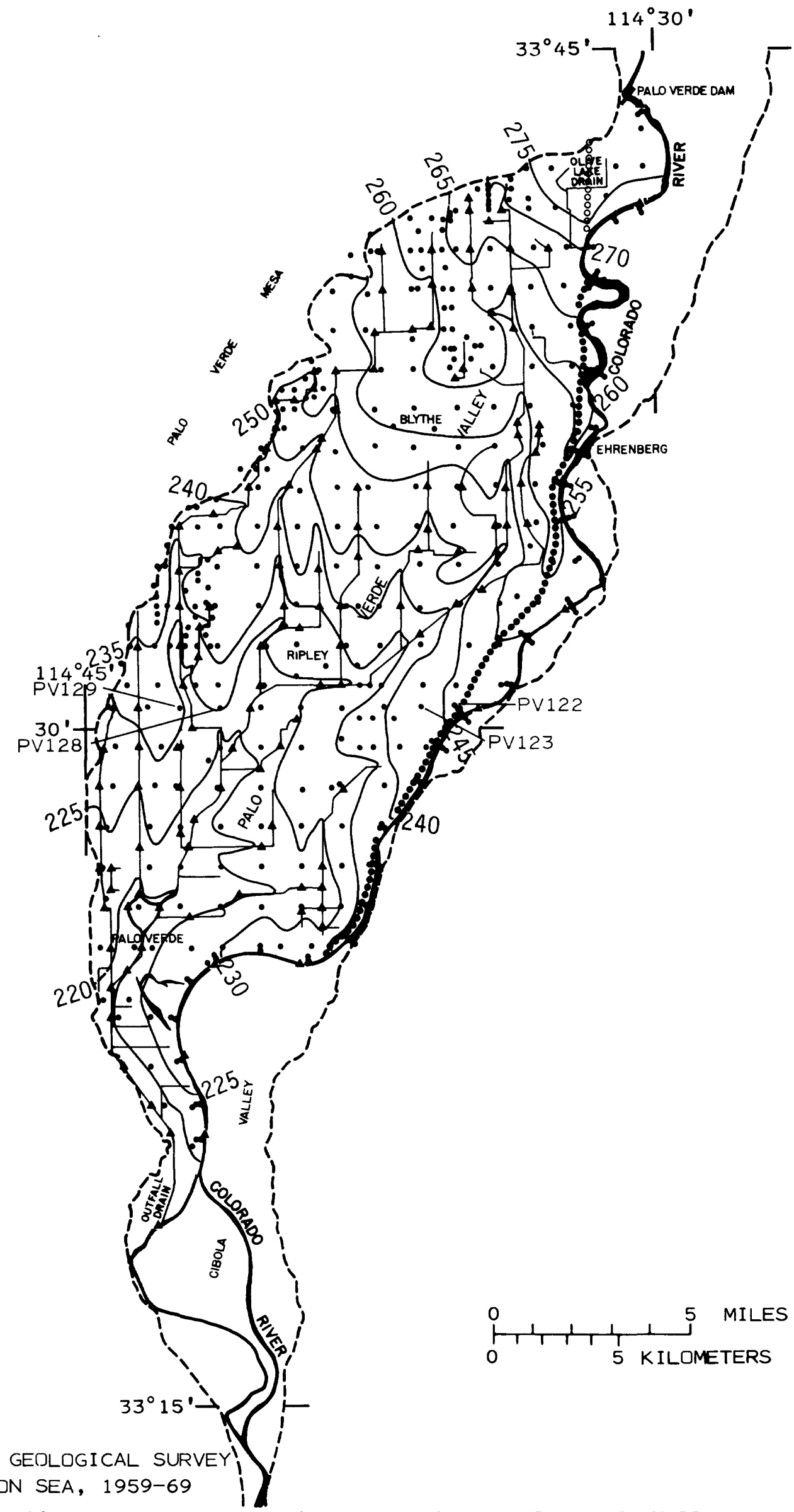

BASE FROM U.S. GEOLOGICAL SUR
$1: 250,000$ SALTON SEA, 1959-69

Figure 12.--Average water-table altitude in $\mathrm{Pa}$ lo Verde Valley, California, 1984 . 
240

WATER-TABLE CONTOUR-Shows average altitude of water table, 1984. Dashed where approximately located. Contour interval 5 feet. Datum is sea level

PV128 ${ }^{\circ}$ SHALLOW OBSERVATION WELL OR PIEZOMETER-Number, PV128, is a well number that corresponds to the hydrographs on figure 17

- STAFF GAGE

DRAINAGE DITCH

GROUND-WATER DIVIDE BETWEEN THE COLORADO RIVER AND DRAINAGE DITCHES - Open symbol where approximately located

COLORADO RIVER FLOOD-PLAIN BOUNDARY

BOUNDARY OF PALO VERDE VALLEY WHERE THE FLOOD-PLAIN AQUIFER IS CONTINUOUS 
water-table altitude of one year from that of the following year. Maps were prepared using a l-foot contour interval (figs. 13-16) to illustrate the magnitude and extent of the annual changes in average water levels. Annual average water-level changes are listed in table 3. Water-level changes are caused by changes in river stage and in the amount of applied irrigation water.

Table 3.-- Annual water-level changes in Palo Verde Valley, california, in feet

\begin{tabular}{lccccc}
\hline & Maximum & Maximum & \multicolumn{3}{c}{ Average water-level change } \\
\cline { 4 - 6 } Yecline & rise & $\begin{array}{c}\text { Area east } \\
\text { of divide }\end{array}$ & $\begin{array}{c}\text { Area west } \\
\text { of divide }\end{array}$ & $\begin{array}{c}\text { Palo Verde } \\
\text { Valley }\end{array}$ \\
\hline & & & -1.32 & -0.01 & -0.16 \\
$1980-81$ & -5.88 & 1.58 & -0.43 & -0.35 & -0.37 \\
$1981-82$ & -6.08 & 4.83 & 1.45 & 0.09 & 0.15 \\
$1982-83$ & -4.58 & 4.62 & 0.67 & 0.30 & 0.33 \\
$1983-84$ & -3.36 & 5.06 & & & \\
\hline
\end{tabular}

Year-to-year changes in average annual water levels were grouped by area. Two areas were identified-the area between the river and easternmost drainage ditch and the rest of the valley. Water levels within about a mile of the river declined as much as $3 \mathrm{ft}$ from 1980 to 1981. Throughout the rest of the valley, water levels rose and declined as much as $2 \mathrm{ft}$ (fig. 13). From 1981 to 1982, water levels declined from 0 to $1 \mathrm{ft}$ over most of the valley. Water levels rose and declined as much as $3 \mathrm{ft}$ in local areas south of Blythe. North of Blythe, water levels rose as much as $2 \mathrm{ft}$ (fig. 14). Water levels from 1982 to 1983 rose from 0 to more than $4 \mathrm{ft}$ within $1.5 \mathrm{mi}$ of the river. In the rest of the valley, except near drainage ditches, water levels declined $1 \mathrm{ft}$, with some local declines of 1 to $3 \mathrm{ft}$. Within $0.4 \mathrm{mi}$ of many of the drainage ditches, water levels rose about $1 \mathrm{ft}$ (fig. 15). From 1983 to 1984, most of the water levels rose from 0 to $1 \mathrm{ft}$. In the area north of Ripley, however, water levels declined as much as $2 \mathrm{ft}$. Water levels rose from 1 to $2 \mathrm{ft}$ along the river in the area adjacent to Cibola Valley and in other local areas throughout the valley (fig. 16).

In the area between the river and easternmost drainage ditch, changes in annual average water levels correlate with changes in river stage, whereas in the rest of the valley the changes correlate with variations in the quantity of applied irrigation water. The quantity of applied irrigation water is proportional to the quantity of water diverted from the river (fig. 4). Flow in the river was lower in 1981 than in 1980 (fig. 7) and water levels declined in the aquifer along the river in 1981 as bank storage returned to the river (fig. 13). 
The quantity of water diverted and therefore the quantity of applied water throughout the valley was greater in 1981 than in 1980 (fig. 6). This greater quantity of applied water caused water levels in the aquifer to rise in 1981 in the area west of the easternmost drainage ditch (fig. 13). From 1981 to 1982, water levels declined in the entire valley (fig. 14) because the quantity of water applied was less in 1982 (fig. 4). Water levels along the river changed less than 1 ft because river stage had the same seasonal variation throughout 1981 and 1982 (fig. 8). Water levels along the river rose from 1982 to 1983 (fig. 15) because river stage was higher in 1983 (fig. 8). High river stage caused a backwater in tributary drainage ditches, which in turn caused a backwater effect on ground-water inflow and increased the water levels along the ditches (fig. 15). Decreased applications in 1983 because of the PIK program (fig. 4) resulted in water-level declines (fig. 15). From 1983 to 1984, water levels rose in most of the area (fig. 16) because part of that acreage was again in production and irrigated (fig. 3). Overall, water levels along the river changed less than $1 \mathrm{ft}$ from 1983 to 1984 owing to changes in river stage because the average river stage did not change significantly between 1983 and 1984 (fig. 8).

Localized changes in average annual water levels occurred from year to year between 1980 and 1984 . Maps showing change in annual average water levels were overlaid on crop maps, and many of the localized water-level changes corresponded to variations in the types of crops grown, especially where fields were left fallow. In several local areas from 1982 to 1983, water levels declined (fig. 15). Several of these areas had crops in 1982 followed by fallow fields in 1983. Many fields throughout the valley were fallow because of the PIK program. Water levels declined as much as $3 \mathrm{ft}$ in many areas where fields were fallow in 1983 because less water was applied to those areas. Water levels rose as much as $2 \mathrm{ft}$ in localized areas from 1983 to 1984 (fig. 16). Many of the areas that had a rise in water level were areas that were fallow in 1983 and had crops in 1984. The rise in water level was caused by water being applied to those areas in 1984.

Hydrographs for selected wells in Palo Verde Valley show water-level changes from 1980 to 1984 and show the relation between location and water-level changes (fig. 17). The hydrograph for well PV122, which is $0.34 \mathrm{mi}$ from the river, illustrates how water levels in wells close to the river follow changes in river stage (fig. 8). High river stage results in higher water levels in the aquifer near the river. Well PV123 is $1.3 \mathrm{mi}$ from the river and water-level changes follow the same trend as PV122. Well PV128 is $6.4 \mathrm{mi}$ from the river between two drainage ditches where changes in water levels correspond to seasonal irrigation applications. The water level rises in summer when the irrigation application is high and declines during winter when less irrigation water is applied. other wells between drainage ditches show the same trend. Well PV129 is $7.4 \mathrm{mi}$ from the river and adjacent to a drainage ditch. 


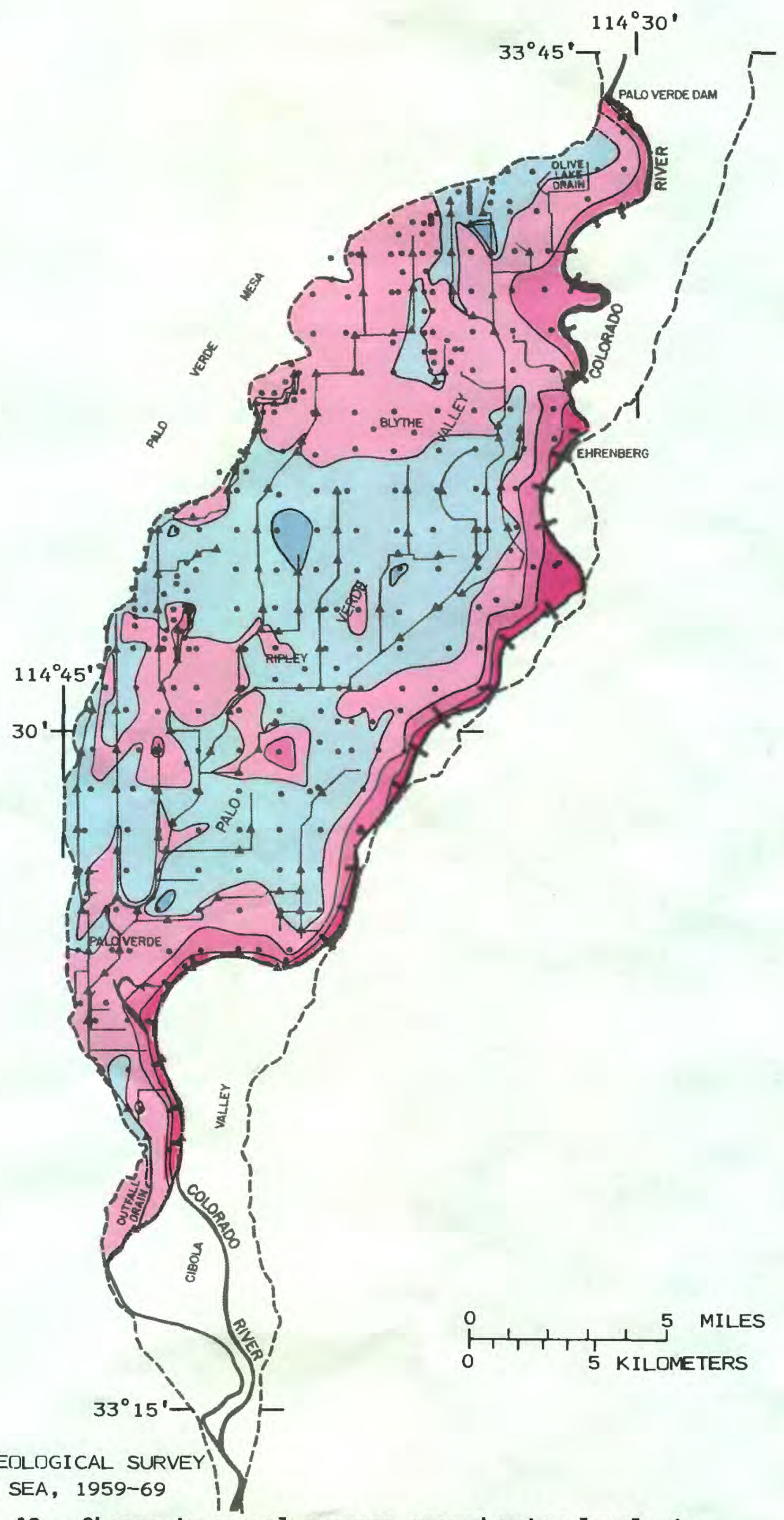

BASE FROM U.S. GEOLOGICAL SURVEY

$1: 250,000$ SALTON SEA, 1959-69

Figure 13.--Change in annual average ground-water levels in Palo Verde Valley, California, 1980-81. 
EXPLANATION

ANNUAL AVERAGE WATER-LEVEL CHANGE, IN FEET

1 to less than 2

0 to less than 1

-1 to less than 0

-2 to less than -1

-3 to less than -2

SHALLOW OBSERVATION WELL OR PIEZOMETER

STAFF GAGE AND CONTINUOUS-RECORD GAGING STATION

DRAINAGE DITCH

COLORADO RIVER FLOOD-PLAIN BOUNDARY

BOUNDARY OF PALO VERDE VALLEY WHERE THE

FLOOD-PLAIN AQUIFER IS CONTINUOUS 


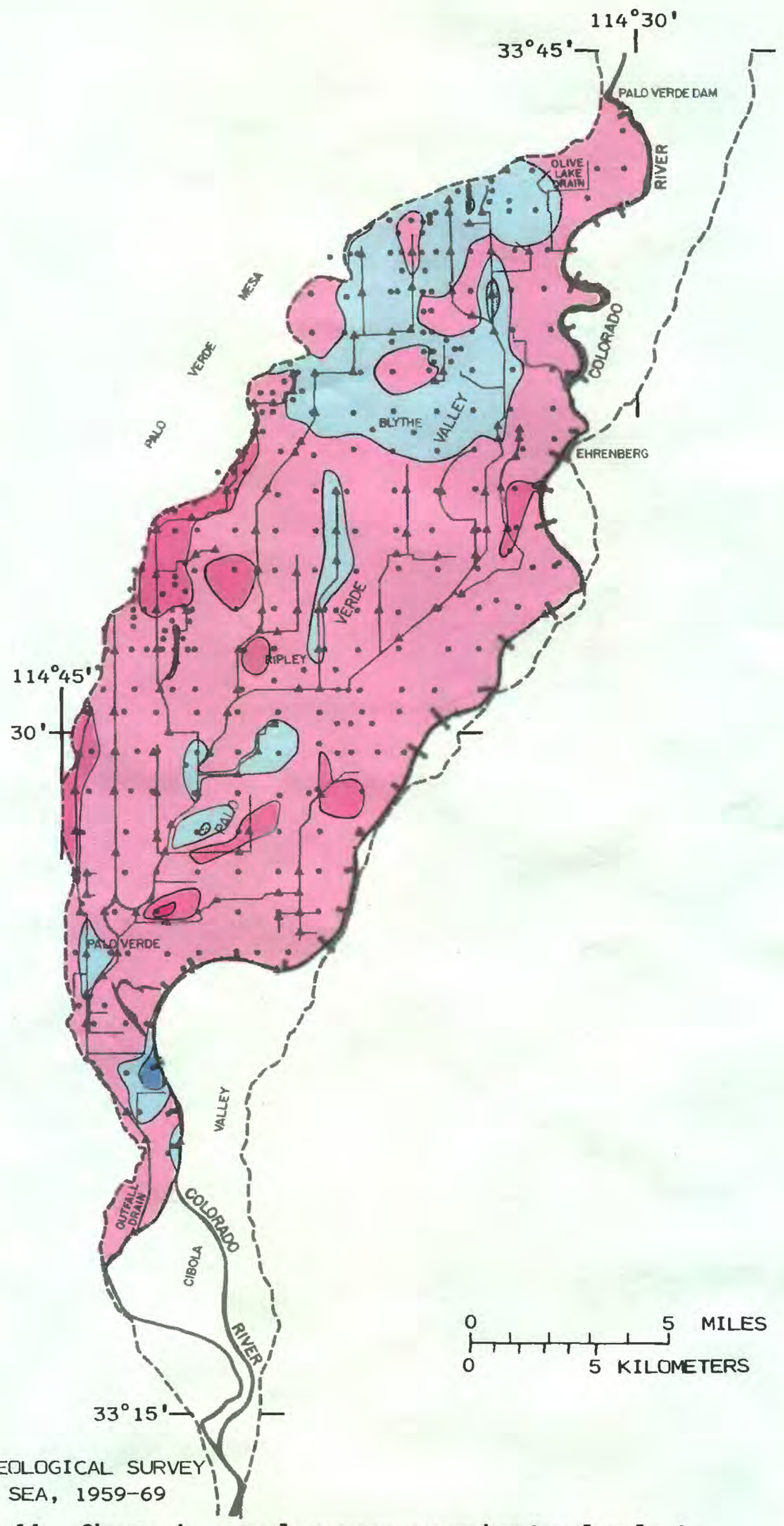

BASE FROM U.S. GEOLOGICAL SURVEY

$1: 250,000$ SALTON SEA, 1959-69

Figure 14.--Change in annual average ground-water levels in Palo Verde Valley, California, 1981-82. 
$E X P L A N A T I O N$

ANNUAL AVERAGE WATER-LEVEL CHANGE, IN FEET

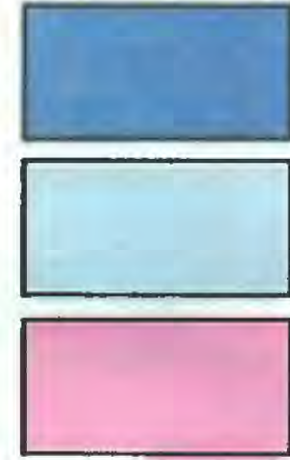

1 to less than 2

0 to less than 1

-1 to less than 0

-2 to less than -1

-3 to less than -2

- SHALLOW OBSERVATION WELL OR PIEZOMETER

* STAFF gAGE AND CONTINUOUS-RECORD GAGING STATION

DRAINAGE DITCH

COLORADO RIVER FLOOD-PLAIN BOUNDARY

BOUNDARY OF PALO VERDE VALLEY WHERE THE

FLOOD-PLAIN AQUIFER IS CONTINUOUS 


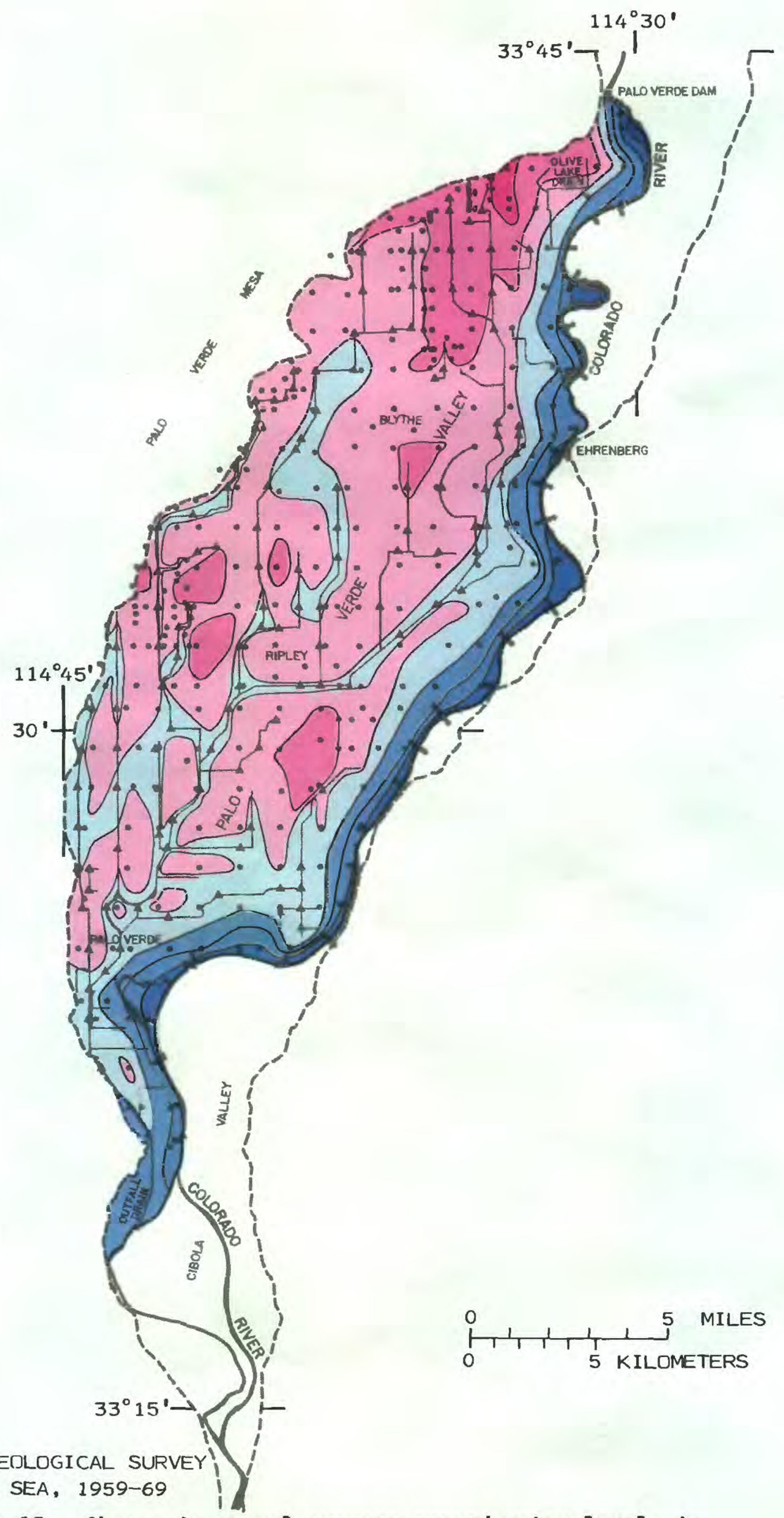

BASE FROM U.S. GEOLOGICAL SURVEY

$1: 250,000$ SALTON SEA, 1959-69

Figure 15.--Change in annual average ground-water levels in Palo Verde Valley, California, 1982-83. 
ANNUAL AVERAGE WATER-LEVEL CHANGE, IN FEET

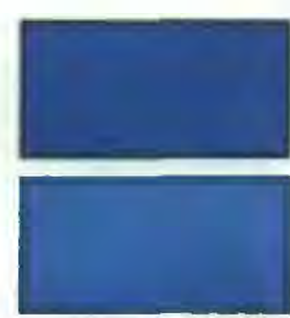

More than 4

3 to less than 4

2 to less than 3

1 to less than 2

0 to less than 1

-1 to less than 0

-2 to less than -1

-3 to less than -2

SHALLOW OBSERVATION WELL OR PIEZOMETER

STAFF GAGE AND CONTINUOUS-RECORD GAGING STATION

DRAINAGE DITCH

COLORADO RIVER FLOOD-PLAIN BOUNDARY

BOUNDARY OF PALO VERDE VALLEY WHERE THE

FLOOD-PLAIN AQUIFER IS CONTINUOUS

Figure 15 


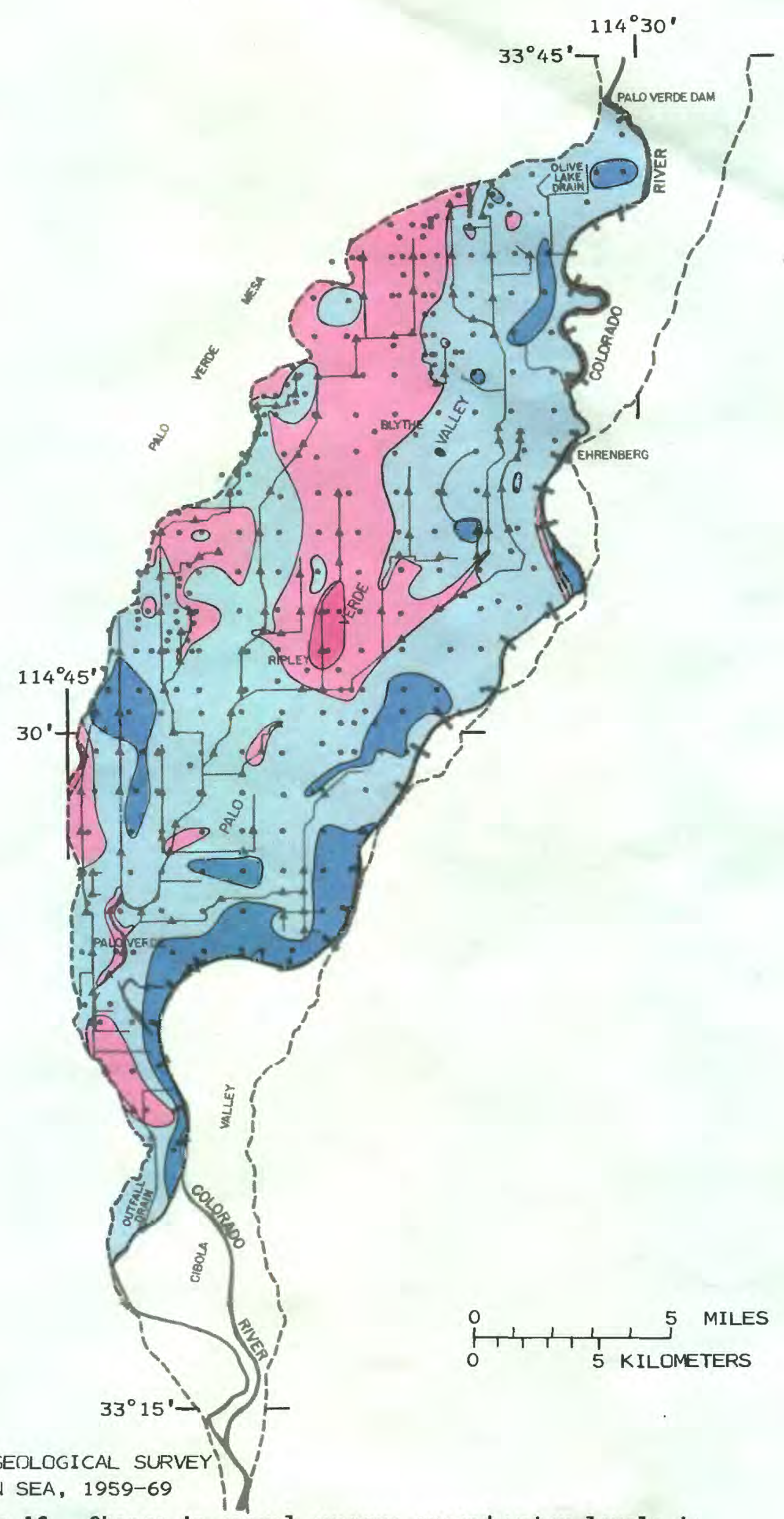

BASE FROM U.S. GEOLOGICAL SURVEY

$1: 250,000$ SALTON SEA, 1959-69

Figure 16.--Change in annual average ground-water levels in

Palo Verde Valley, California, 1983-84. 
EXPLANATION

ANNUAL AVERAGE WATER-LEVEL CHANGE, IN FEET

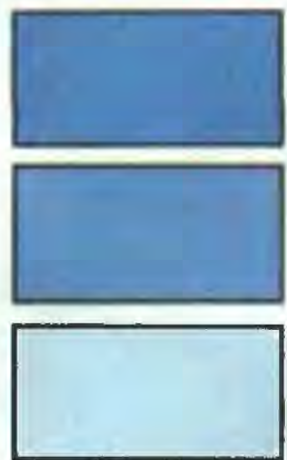

2 to less than 3

1 to less than 2

0 to less than 1

-1 to less than 0

-2 to less than -1

SHALLOW OBSERVATION WELL OR PIEZOMETER

STAFF GAGE AND CONTINUOUS-RECORD GAGING STATION

DRAINAGE DITCH

COLORADO RIVER FLOOD-PLAIN BOUNDARY

BOUNDARY OF PALO VERDE VALLEY WHERE THE

FLOOD-PLAIN AQUIFER IS CONTINUOUS

Figure 16 


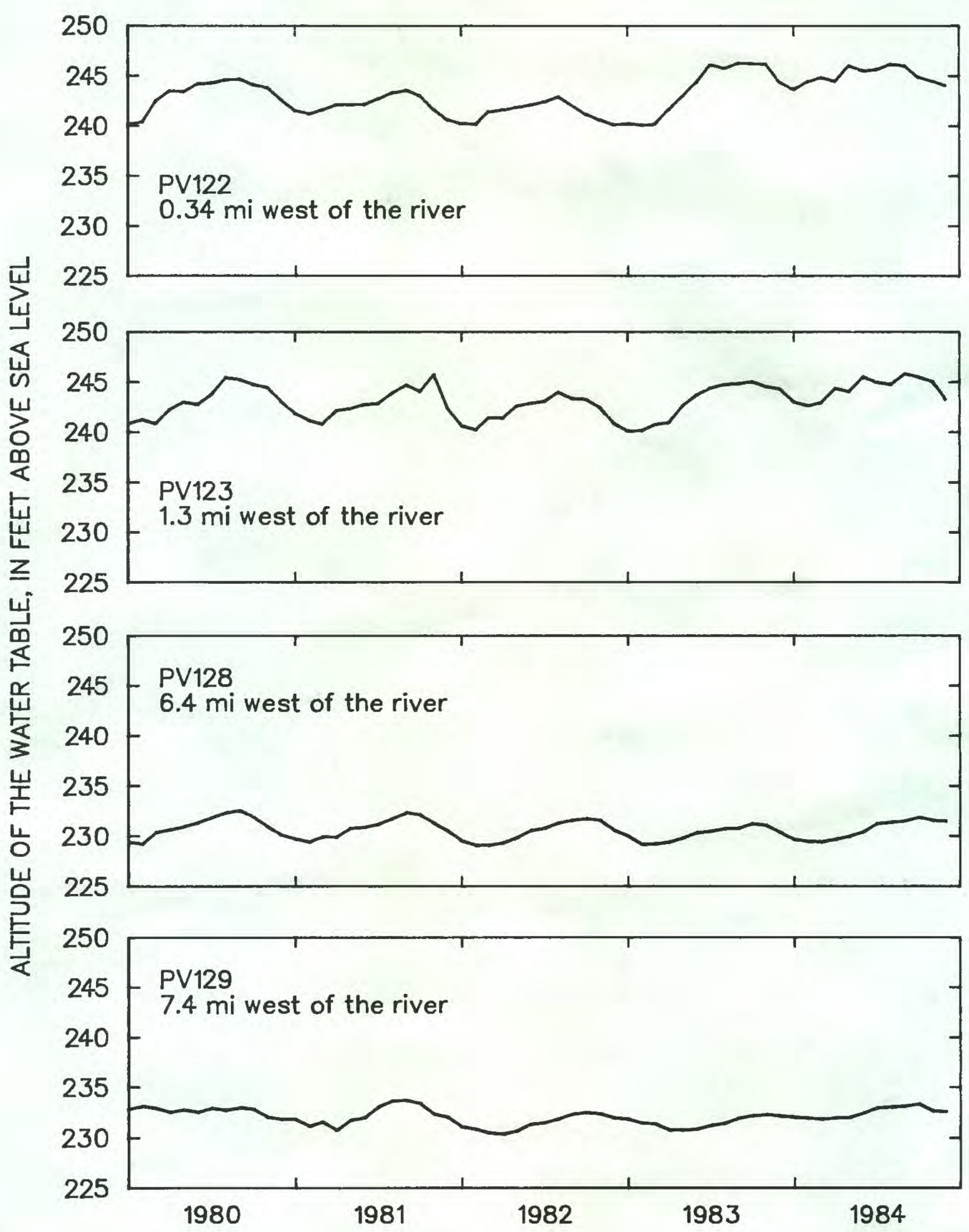

Figure 17.--Water levels in selected wells in Palo Verde Valley, Cal ifornia, 1980-84. 
Water-level changes near drainage ditches follow the same trend associated with irrigation, but the amount of change is less than for areas between drainage ditches.

\section{Change in storage}

Change in ground-water storage was calculated for each of the two drainage areas (table 4) as the product of changes in ground-water levels, areas of change, and specific yield. Change in storage for Palo Verde Valley was calculated as the sum of the changes in the two drainage areas. Changes in ground-water levels were estimated as the differences between the annual average water levels to approximate the net change in ground-water storage. Annual average water levels provide the best defined surfaces of the water table from year to year. Areas of change were determined by integrating the areas between the contours on figures 13-16. Metzger and others (1973, p. 72) measured a specific yield of 0.32 for sediments in Palo verde Valley above the water table, which was used for calculating changes in storage. Specific yield was calculated from soil-moisture studies using a neutron moisture probe at 16 sites throughout the flood plain.

Table 4.--Change in storage for Palo Verde Valley, California, 1981-84, in acre-feet

\begin{tabular}{lcccc}
\hline & 1981 & 1982 & 1983 & 1984 \\
\hline $\begin{array}{l}\text { Area drained by } \\
\text { drainage ditches }\end{array}$ & -400 & $-10,900$ & 2,900 & 10,200 \\
$\begin{array}{l}\text { Area drained by } \\
\text { the river }\end{array}$ & $-5,300$ & $-1,700$ & 2,300 & 1,400 \\
$\begin{array}{c}\text { Total for Palo } \\
\text { Verde Valley }\end{array}$ & $-5,700$ & $-12,600$ & 5,200 & 11,600 \\
\hline
\end{tabular}

The estimates of change in storage are small relative to the estimates of consumptive use by vegetation and consumptive use of river water. Therefore, the accuracy with which change in storage is estimated does not significantly affect either the estimates of consumptive use by, vegetation calculated in a water budget or the estimates of consumptive use of Colorado River water calculated as measured diversions minus return flows. The accuracy with which change in storage is estimated does significantly affect the estimate of groundwater return flow calculated in a water budget because change in storage is of the same magnitude as the estimates of ground-water return flow. 


\section{CONSUMPTIVE USE}

Consumptive use by vegetation for the area drained by drainage ditches was calculated as the residual in a water budget (table 5) that accounted for inflow as (1) water diverted from the river for application to fields, (2) effective precipitation, (3) ground-water inflow and tributary runoff from the area west of the flood plain, and (4) seepage from the Colorado River. Outflow occurred as (1) surface-water discharge to the river from the drainage ditches, (2) consumptive use by vegetation, (3) ground-water outflow to the area west of the flood plain, and (4) pumpage. Diversions and surface-water return flows, the largest components in the budget, are measured. Change in ground-water storage was calculated as the product of annual average changes in ground-water levels, areas of change, and specific yield. Consumptive use per unit vegetated area from the area drained by drainage ditches was used to estimate consumptive use by vegetation for the area drained by the river. The vegetated area consists of cropped areas, including multiple cropping, and areas of phreatophytes (table 7). Total consumptive use by vegetation for Palo verde valley is the sum of consumptive use from both ground-water drainage areas.

The surface-water diversion to the area drained by drainage ditches was calculated by determining the quantity of water diverted from the river at Palo Verde Dam that (1) was applied to fields, (2) seeped from the canals, (3) spilled to the river, (4) was wasted to drainage ditches, (5) evaporated from canals, and (6) was diverted out of the flood plain to Palo Verde Mesa and by summing the proportion of each component that occurred in the drainage area (table 6). The applied water was apportioned between the two drainage areas using the percentages determined from irrigation requirements (table 7) the volume of water per unit area required to grow each crop-in order to account for the effect of areal cropping distributions on the areal distribution of applied water (Owen-Joyce, 1984, p. 27 ). Canal seepage and evaporation were apportioned by canal length (Owen-Joyce, 1984, p. 29). The quantities of water spilled to the river and diverted to the mesa were measured by Palo Verde Irrigation District.

Ground-water inflow to and outflow from, tributary runoff from the area west of the flood plain, and ground-water pumpage were estimated in previous studies. Ground-water inflow was estimated to be 9,500 acre-ft/yr, and ground-water outflow was estimated to be 4,700 acre-ft/yr (Owen-Joyce, 1984, p. 15-16). Tributary runoff, some of which recharges the aquifer and some of which is consumed by phreatophytes, was estimated to be 3,200 acre-ft/yr (Metzger and others, 1973). Ground-water pumpage consumptively used for domestic, municipal, and industrial purposes was estimated to be 2,000 acre-ft/yr (Bookman-Edmonston Engineering, Inc., 1976, p. 37). 
Table 5.--Water budgets for the area drained by drainage ditches in Palo verde Valley, California, 1981-84, in acre-feet per year

\begin{tabular}{lllll}
\hline & 1981 & 1982 & 1983 & 1984 \\
\hline
\end{tabular}

Inflow:

\begin{tabular}{|c|c|c|c|c|}
\hline Surface-water diversion... & 836,000 & 777,000 & 668,700 & 715,400 \\
\hline Effective precipitation... & 3,100 & 16,200 & 10,600 & 39,400 \\
\hline $\begin{array}{l}\text { Ground-water inflow from } \\
\text { the area west of the } \\
\text { flood plain........... }\end{array}$ & 9,500 & 9,500 & 9,500 & 9,500 \\
\hline Tributary runoff......... & 3,200 & 3,200 & 3,200 & 3,200 \\
\hline $\begin{array}{l}\text { Seepage from the colorado } \\
\text { River................ }\end{array}$ & 3,100 & 0 & 45,400 & 27,000 \\
\hline Total & 854,900 & 805,900 & 737,400 & 794,500 \\
\hline
\end{tabular}

Outflow:

\begin{tabular}{|c|c|c|c|c|}
\hline from drainage ditches... & 419,500 & 408,200 & 381,900 & 426,400 \\
\hline $\begin{array}{l}\text { Consumptive use by vege- } \\
\text { tation }^{1} \ldots \ldots \ldots \ldots \ldots \ldots \ldots\end{array}$ & 429,100 & 401,900 & 345,900 & 351,200 \\
\hline 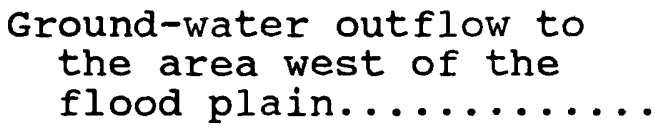 & 4,700 & 4,700 & 4,700 & 4,700 \\
\hline 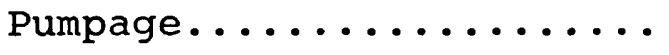 & 2,000 & 2,000 & 2.000 & 2,000 \\
\hline Total.......... & 855,300 & 816,800 & 734,500 & 784,300 \\
\hline ange in storage: & -400 & $-10,900$ & 2,900 & 10,200 \\
\hline
\end{tabular}

${ }^{1}$ Consumptive use calculated as inflow minus outflow minus change in storage. 
Table 6.--Estimates of surface-water diversions to irrigated land in Palo Verde Valley, California, 1981-84, in acre-feet per year

\section{Diversion to Palo
Verde Valley:
Surface-water diversion}

at Palo Verde Dam $^{1}$

Canal seepage ${ }^{2}$

Spills to river ${ }^{3}$

Regulatory waste to

drainage ditches ${ }^{4}$

Diversion to Palo Verde Mesa $^{4}$

Evaporation from canals ${ }^{5}$

Subtotal of water loss

Net water applied to irrigated land

1982

1983

1984

$\underline{\underline{1,006,000}}$

125,00

125,000

$\underline{\underline{786,700}}$

$\underline{\underline{834,900}}$

65,600

68,200

125,000

125,000

22,300

17,200

14,200

10,300

17,100

15,900

13,200

12,800

5,000

5,000

5,000

5,000

$\underline{\underline{235,000}}$

$\underline{\underline{231,300}}$

$\underline{\underline{231,900}}$

$\underline{\underline{222,100}}$

$771,000 \quad 710,700$

554,800

612,800

Diversion to area

west of divide:

Surface water applied

to irrigated land

$696,984 \quad 641,762 \quad 529,834 \quad 580,322$

Regulatory waste to

drainage ditches

Canal seepage

22,300

17,200

$14,200 \quad 10,300$

$112,250 \quad 113,500 \quad 119,875 \quad 120,000$

Evaporation from canals

4,490

4,540

4,795

4,800

Total diversion

(rounded)

$836,000 \quad 777,000$

668,700

715,400 
Table 6.--Estimates of surface-water diversions to irrigated land in Palo Verde Valley, California, 1981-84, in acre-feet per year--Continued

\begin{tabular}{|c|c|c|c|c|}
\hline & 1981 & 1982 & 1983 & 1984 \\
\hline \multicolumn{5}{|l|}{$\begin{array}{l}\text { Diversion to area } \\
\text { east of divide: }\end{array}$} \\
\hline $\begin{array}{c}\text { Surface water applied } \\
\text { to irrigated land }\end{array}$ & 74,016 & 68,938 & 24,966 & 32,478 \\
\hline $\begin{array}{c}\text { Regulatory waste to } \\
\text { drainage ditches }\end{array}$ & 0 & 0 & 0 & 0 \\
\hline Canal seepage & 12,750 & 11,500 & 5,125 & 5,000 \\
\hline Evaporation from canals & 510 & 460 & 205 & 200 \\
\hline $\begin{array}{l}\text { Total diversion } \\
\text { (rounded) }\end{array}$ & 87,300 & 80,900 & 30,300 & 37,700 \\
\hline
\end{tabular}
Blythe.

${ }^{1}$ Gaged by the U.S. Geological survey, Palo Verde Canal near ${ }^{2}$ Estimated by Bookman-Edmonston Engineering, Inc. (1976, p. 35) -

${ }^{3}$ Measured and computed by the U.S. Geological survey (see table 1).

${ }^{4}$ Measured by Palo Verde Irrigation District (R. E. Henning, written commun., 1983-85). p. 36).

5 Estimated by Bookman-Edmonston Engineering, Inc. (1976,

Seepage from the colorado River occurred along some reaches of the river where the ground-water divide and the river coexist. In 1981, seepage was estimated to be 3,100 acre-ft (Owen-Joyce, 1984, p. 16). In 1982, seepage did not occur along reaches adjacent to Palo verde Valley. In 1983, seepage occurred along $19.9 \mathrm{mi}$ of the river and was estimated to be 45,400 acre-ft. Ground-water gradients ranged from 1.7 to $13.2 \mathrm{ft} / \mathrm{mi}$ in the losing reaches. In 1984 , seepage occurred along $9.9 \mathrm{mi}$ of river and ground-water gradients ranged from 4.5 to $11.1 \mathrm{ft} / \mathrm{mi}$; seepage was estimated to be 27,000 acre-ft. A transmissivity of 53,000 $\mathrm{ft}^{2} / \mathrm{d}$ (Metzger and others, 1973, p. 68) was used to estimate the seepage in all reaches. 


\section{8}

Table 7.--Estimates of irrigation requirements and evapotranspiration by vegetation in Palo Verde Valley, California, 1981-84

\begin{tabular}{|c|c|c|c|c|c|c|c|c|c|c|c|c|}
\hline \multirow{2}{*}{ Year } & \multirow{2}{*}{$\begin{array}{l}\text { Vegetation } \\
\text { type }\end{array}$} & \multirow{2}{*}{$\begin{array}{l}\text { Irrigation } \\
\text { requirement, } \\
\text { in feet }\end{array}$} & \multirow{2}{*}{$\begin{array}{l}\text { Evapotran- } \\
\text { spiration, } \\
\text { in feet }\end{array}$} & \multicolumn{3}{|c|}{ Area, in acres } & \multicolumn{3}{|c|}{ Irrigation requirement, in acre-feet } & \multicolumn{3}{|c|}{ Evapotranspiration, in acre-feet } \\
\hline & & & & $\begin{array}{l}\text { West of } \\
\text { divide }\end{array}$ & $\begin{array}{l}\text { East of } \\
\text { divide }\end{array}$ & Total & $\begin{array}{c}\text { West of } \\
\text { divide }\end{array}$ & $\begin{array}{r}\text { East of } \\
\text { divide }\end{array}$ & Total & $\begin{array}{c}\text { West of } \\
\text { divide }\end{array}$ & $\begin{array}{c}\text { East of } \\
\text { divide }\end{array}$ & Total \\
\hline \multirow{4}{*}{1981} & $\begin{array}{l}\text { Alfalfa } \\
\text { Cotton } \\
\text { Grain } \\
\text { Other }\end{array}$ & $\begin{array}{r}19.5 \\
15.7 \\
13.3 \\
4.0\end{array}$ & $\begin{array}{l}25.3 \\
23.2 \\
21.9 \\
31.9\end{array}$ & $\begin{array}{l}31,003 \\
32,198 \\
19,199 \\
20,700 \\
\end{array}$ & $\begin{array}{l}4,574 \\
2,090 \\
1,600 \\
1,406 \\
\end{array}$ & $\begin{array}{l}35,577 \\
34,288 \\
20,799 \\
22,106 \\
\end{array}$ & $\begin{array}{r}294,529 \\
183,529 \\
63,357 \\
82,800 \\
\end{array}$ & $\begin{array}{r}43,453 \\
11,913 \\
5,280 \\
5,624 \\
\end{array}$ & $\begin{array}{r}337,982 \\
195,442 \\
68,637 \\
88,424 \\
\end{array}$ & $\begin{array}{r}164,316 \\
103,034 \\
36,478 \\
39,330 \\
\end{array}$ & $\begin{array}{r}24,242 \\
6,688 \\
3,040 \\
2,671 \\
\end{array}$ & $\begin{array}{r}188,558 \\
109,722 \\
39,518 \\
42,001 \\
\end{array}$ \\
\hline & Subtotal & & & 103,100 & 9,670 & 112,770 & 624,215 & 66,270 & 690,485 & 343,158 & 36,641 & 379,799 \\
\hline & Phreatophytes & -... & 43.4 & 4,239 & $\underline{2,697}$ & 6,936 & $z \ldots \ldots$ & $\underline{-\cdots-\cdot}$ & -....... & 14,413 & $\underline{9,170}$ & 23,583 \\
\hline & Total & & & 107,339 & 12,367 & 119,706 & 624,215 & 66,270 & 690,485 & 357,571 & 45,811 & 403,382 \\
\hline \multirow[t]{5}{*}{1982} & Crops & & & & & & & & & & & \\
\hline & $\begin{array}{l}\text { Alfalfa } \\
\text { Cotton } \\
\text { Grain } \\
\text { Other }\end{array}$ & $\begin{array}{r}19.5 \\
15.7 \\
13.3 \\
4.0\end{array}$ & $\begin{array}{l}25.3 \\
23.2 \\
21.9 \\
{ }^{3} 1.9\end{array}$ & $\begin{array}{r}30,008 \\
28,221 \\
17,375 \\
25,229 \\
\end{array}$ & $\begin{array}{l}3,817 \\
2,685 \\
1,002 \\
2,491 \\
\end{array}$ & $\begin{array}{r}33,825 \\
30,906 \\
18,377 \\
27,720 \\
\end{array}$ & $\begin{array}{r}285,076 \\
160,860 \\
57,337 \\
100,916 \\
\end{array}$ & $\begin{array}{r}36,262 \\
15,304 \\
3,307 \\
9,964 \\
\end{array}$ & $\begin{array}{r}321,338 \\
176,164 \\
60,644 \\
110,880 \\
\end{array}$ & $\begin{array}{r}159,042 \\
90,307 \\
33,012 \\
47,935 \\
\end{array}$ & $\begin{array}{r}20,230 \\
8,592 \\
1,904 \\
4,733 \\
\end{array}$ & $\begin{array}{r}179,272 \\
98,899 \\
34,916 \\
52,668 \\
\end{array}$ \\
\hline & Subtotal & & & 100,833 & 9,995 & 110,828 & 604,189 & 64,837 & 669,026 & 330,296 & 35,459 & 365,755 \\
\hline & Phreatophytes & $\cdots$ & 43.4 & 4,285 & 2,651 & 6,936 & $=\ldots$ & $\ldots$ & $\ldots \ldots$ & 14,569 & 9,013 & 23,582 \\
\hline & Total & & & 105,118 & 12,646 & 117,764 & 604,189 & 64,837 & 669,026 & 344,865 & 44,472 & 389,337 \\
\hline \multirow[t]{5}{*}{1983} & Crops & & & & & & & & & & & \\
\hline & $\begin{array}{l}\text { Alfalfa } \\
\text { Cotton } \\
\text { Grain } \\
\text { Other }\end{array}$ & $\begin{array}{r}19.5 \\
15.7 \\
13.3 \\
4.0\end{array}$ & $\begin{array}{l}25.3 \\
23.2 \\
21.9 \\
31.7\end{array}$ & $\begin{array}{l}31,614 \\
16,889 \\
15,060 \\
28,387 \\
\end{array}$ & $\begin{array}{r}2,145 \\
556 \\
330 \\
511 \\
\end{array}$ & $\begin{array}{l}33,759 \\
17,445 \\
15,390 \\
28,898 \\
\end{array}$ & $\begin{array}{r}300,333 \\
96,267 \\
49,698 \\
113,548 \\
\end{array}$ & $\begin{array}{r}20,378 \\
3,169 \\
1,089 \\
2,044 \\
\end{array}$ & $\begin{array}{r}320,711 \\
99,436 \\
50,787 \\
115,592 \\
\end{array}$ & $\begin{array}{r}167,554 \\
54,045 \\
28,614 \\
48,258 \\
\end{array}$ & $\begin{array}{r}11,369 \\
1,779 \\
627 \\
\quad 869 \\
\end{array}$ & $\begin{array}{r}178,923 \\
55,824 \\
29,241 \\
49,127 \\
\end{array}$ \\
\hline & Subtotal & & & 91,950 & 3,542 & 95,492 & 559,846 & 26,680 & 586,526 & 298,471 & 14,644 & 313,115 \\
\hline & Phreatophytes & $\cdots$ & 43.4 & 6,202 & 734 & 6,936 & $\ldots$ & - & - & 21,087 & 2,496 & 23,583 \\
\hline & Tota! & & & 98,152 & 4,276 & 102,428 & 559,846 & 26,680 & 586,526 & 319,558 & 17,140 & 336,698 \\
\hline \multirow[t]{4}{*}{1984} & Crops & & & & & & & & & & & \\
\hline & Subtotal & & & 105,925 & 5,276 & 111,201 & 635,968 & 35,610 & 671,578 & 342,592 & 19,355 & 361,947 \\
\hline & Phreatophytes & $\cdots$ & 43.4 & 5,679 & 1,257 & 6,936 & -....... & $\underline{\cdots-\cdots}$ & $\ldots$ & 19,309 & 4,274 & 23,583 \\
\hline & Total & & & 111,604 & 6,533 & 118,137 & 635,968 & 35,610 & 671,578 & 361,901 & 23,629 & 385,530 \\
\hline
\end{tabular}

\footnotetext{
1S. H. Stipe (U.S. Economic Research Service, written commun., 1983).
} 1983)

${ }^{2}$ Determined by U.S. Soil Conservation Service on the basis of soil-moisture depletion studies in Parker Valley (H. C. Millsaps, oral commun.,

${ }^{3}$ Calculated as area-weighted average of empirically determined evapotranspiration for other crops.

${ }^{4}$ Boyle Engineering Corp. (1976, p. 11-7)

Consumptive use by vegetation for the area drained by the river (table 8) was estimated using the consumptive use per unit vegetated area determined for the area drained by drainage ditches (table 8) multiplied by the vegetated area in the area drained by the river (table 7) and adjusted for the unequal distribution of vegetation types in the two drainage areas (table 9). An analysis of evapotranspiration by vegetation types using empirically determined evapotranspiration (table 7) indicated that evapotranspiration per unit vegetated area was higher in the area drained by the river than in the area drained by the drainage ditches (table 9 ). The percent difference in evapotranspiration between the two drainage areas was used to adjust consumptive use for the unequal distribution of vegetation types. The higher evapotranspiration per unit vegetated area is caused by a greater percentage of the cultivated area planted with alfalfa and more phreatophytes per 
Table 8.--Estimates of consumptive use by vegetation in Palo Verde Valley, California, 1981-84

\begin{tabular}{|c|c|c|c|c|c|c|c|c|}
\hline & \multicolumn{4}{|c|}{$\begin{array}{c}\text { Consumptive use, in } \\
\text { acre-feet }\end{array}$} & \multicolumn{4}{|c|}{$\begin{array}{l}\text { Consumptive use, } \\
\text { in feet }\end{array}$} \\
\hline & 1981 & 1982 & 1983 & 1984 & 1981 & 1982 & 1983 & 1984 \\
\hline $\begin{array}{l}\text { Area drained } \\
\text { by drainage } \\
\text { ditches...... }\end{array}$ & 429,100 & 401,900 & 345,900 & 351,200 & 4.00 & 3.82 & 3.52 & 3.15 \\
\hline $\begin{array}{l}\text { Area drained } \\
\text { by the river.. }\end{array}$ & 54,900 & 51,700 & 18,500 & 23,100 & 4.44 & 4.09 & 4.33 & 3.53 \\
\hline $\begin{array}{l}\text { Palo Verde } \\
\text { Valley........ }\end{array}$ & 484,000 & 453,600 & 364,400 & 374,300 & 4.04 & 3.85 & 3.56 & 3.17 \\
\hline
\end{tabular}

${ }^{1}$ Calculated as consumptive use per unit vegetated area (table 7)- the area of crops plus phreatophytes.

Table 9.--Evapotranspiration per unit area by vegetation in Palo Verde Valley, California, 1981-84

\begin{tabular}{lccc}
\hline Year & \multicolumn{2}{c}{ Evapotranspiration, in feet } & $\begin{array}{c}\text { Percent } \\
\text { difference }\end{array}$ \\
\cline { 2 - 4 } & $\begin{array}{l}\text { Area drained by } \\
\text { drainage ditches }\end{array}$ & $\begin{array}{l}\text { Area drained } \\
\text { by the river }\end{array}$ & \\
\hline 1981 & 3.33 & 3.70 & 11 \\
1982 & 3.28 & 3.52 & 7 \\
1983 & 3.28 & 4.01 & 23 \\
1984 & 3.24 & 3.62 & 12 \\
\hline
\end{tabular}

unit area. Consumptive use for Palo verde valley is the sum of consumptive use for the two ground-water drainage areas (table 8).

A sensitivity analysis was done to determine the change in computed consumptive use by vegetation for a specified change of a primary variable. The sensitivity values for consumptive use in table 10 indicate that consumptive use is most sensitive to the diversion at Palo Verde Dam and the discharge from drainage ditches to the river from the area west of the divide; both variables are measured quantities. The movement of the ground-water divide from year to year and the change in storage do not significantly affect the computation of 

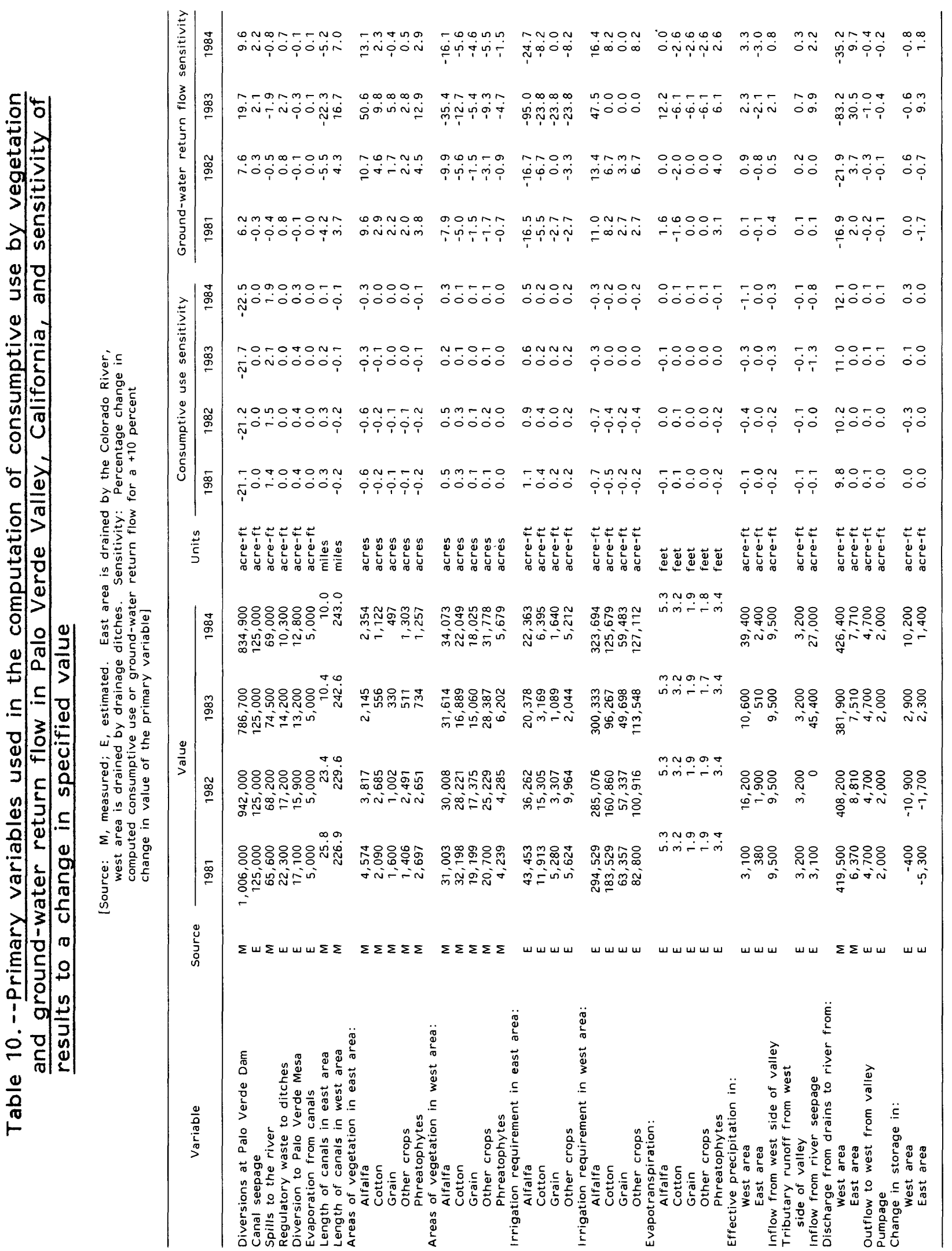
consumptive use by vegetation. Change in storage from 1981 to 1984 was 1 to 3 percent of consumptive use by vegetation for each year. For a valley drained by a network of drainage ditches with one point of diversion, the estimate of consumptive use by vegetation depends mostly on the accuracy with which the diversion and surface-water return flows are measured.

Comparisons were made using the values of consumptive use by vegetation and evapotranspiration for Palo verde valley and also using the values per unit vegetated area. Evapotranspiration is the major part of consumptive use by vegetation and, during 1981 and 1982, evapotranspiration was less than consumptive use by vegetation; in 1983 and 1984 that relation reversed (fig. 18). The only major difference between the two time periods, 1981-82 and 1983-84, was the rise in river stage from flood-control releases at Parker Dam. The reverse relation between consumptive use and evapotranspiration in 1983-84 may indicate that the amount of seepage from the river was underestimated. In a comparison of the two values per unit vegetated area, the reverse relation does not appear until 1984 (fig. 19). Both values consistently decrease from 1981 to 1984 , but the difference between the two values decreases each year until they reverse in 1983 or 1984 .

Consumptive use by vegetation in Palo Verde valley decreases with decreases in the quantity of water diverted but consumptive use per unit vegetated area does not follow the same trend. Consumptive use by vegetation decreased from 1981 to 1983 (fig. 18; table 8) and correlates with decreasing vegetated area (table 7$)$. In 1984, however, when the vegetated area increased to an amount between the 1981 and 1982 areas, consumptive use by vegetation increased slightly but remained far less than consumptive use by vegetation in 1981 and 1982 . Consumptive use per unit area consistently decreased from 1981 to 1984 (fig. 19; table 8). The decrease does not correlate with changes in any one component and probably is the combined effect from changes in a number of the components. Changes from higher water-use crops-alfalfa and cotton- to lower water-use crops-grains and other crops-(fig. 3) could account for some, but not all, of the difference. The quantity of water diverted from the river each year has decreased; this decrease may indicate a change in irrigation practices that reduce consumptive use by vegetation.

The estimate of each component for input into the water budget affects the overall calculation of consumptive use by vegetation, and knowing the limitations of those estimates can help in analyzing the year-to-year variations. In 1984 effective precipitation was substantially higher than that in preceding years (table 5) and therefore could account for a lower consumptive use by vegetation of colorado River water but does not account for the total difference. Higher rainfall in 1984 may have increased tributary runoff above the average value used in the water budget, but data are not available on the 


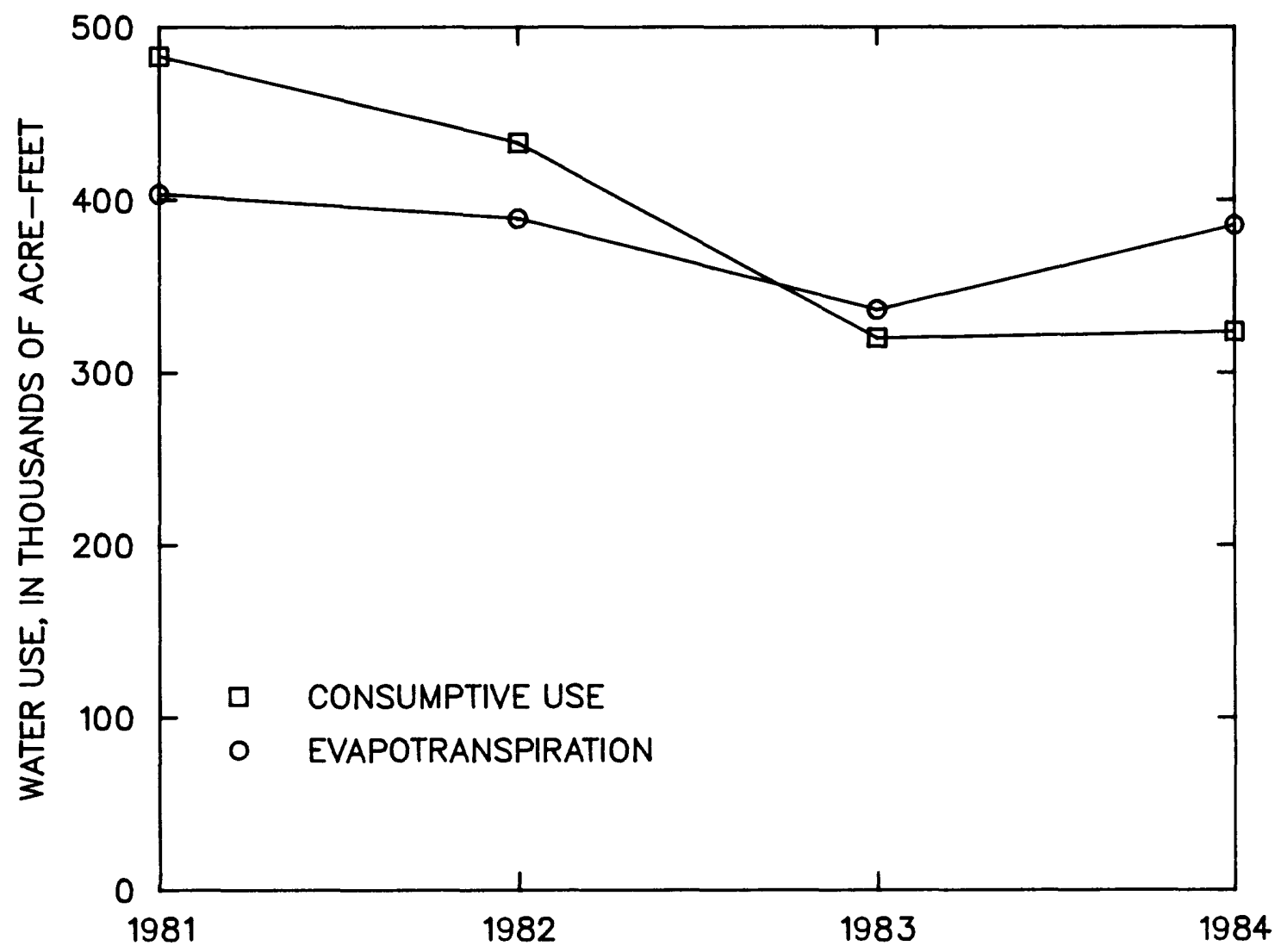

Figure 18.--Comparison of consumptive use by vegetation and evapotranspiration in Palo Verde Valley, Cal ifornia, 1981-84.

quantity of runoff in 1984. An increase in the tributary runoff component in the water budget would increase consumptive use by vegetation. Variations from year to year in other climatic factors such as solar radiation, wind, and minimum and maximum air and soil temperatures could also contribute to variations in evapotranspiration. Sustained high river stage in 1984 caused water to be retained in the aquifer and caused backwater in the network of drainage ditches; therefore, a large quantity of water in the aquifer originated directly from infiltration from the river rather than from applied irrigation water. The differences in consumptive use by vegetation from year to year could be an indication that the estimate of transmissivity used to compute seepage from the river is too small.

\section{GROUND-WATER RETURN FLOW}

Annual ground-water return flow to the river for 1981 to 1984 was computed using water budgets (table 11). Annual 


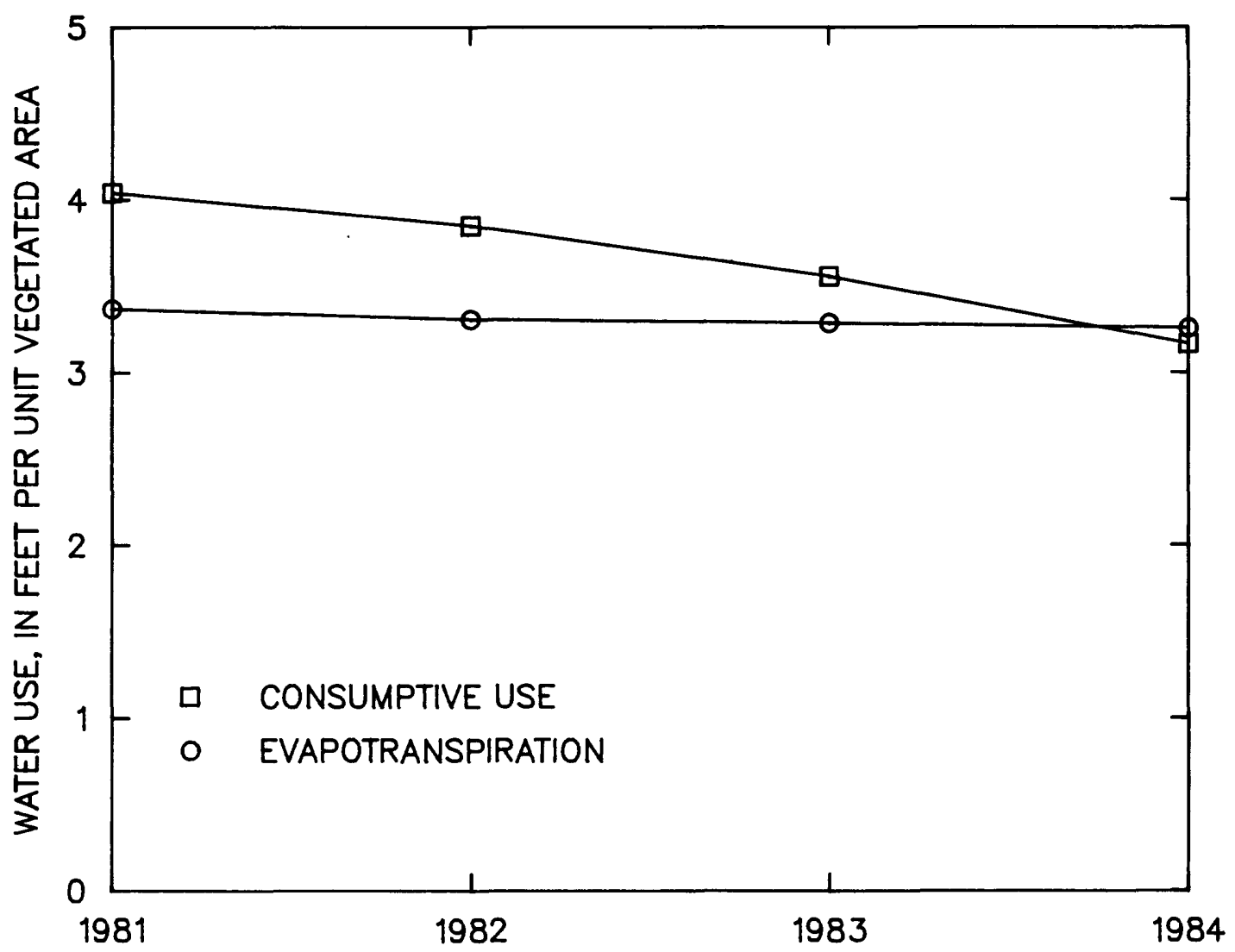

Figure 19.--Comparison of consumptive use by vegetation and evapotranspiration per unit vegetated area in Palo Verde Valley, California, 1981-84.

diversions to the area drained by the river were estimated as shown in table 6 . Consumptive use by vegetation was estimated using the consumptive use per unit area determined for the area drained by drainage ditches multiplied by the vegetated area in the area drained by the river and adjusted for the unequal distribution of vegetation types in the drainage areas as described in the section entitled "Consumptive Use."

A sensitivity analysis was done to determine the change in computed ground-water return flow for a specified change in the value of a primary variable. The sensitivity values for ground-water return flow in table 10 indicate that ground-water return flow is most sensitive to discharge from drainage ditches to the river; various irrigation requirements, particularly for alfalfa; various crop areas, particularly those of alfalfa; and the diversion at Palo Verde Dam. All these components are significant in calculating consumptive use by vegetation; therefore, the estimate of ground-water return flow is most sensitive to consumptive use by vegetation and the 
Table 11.--Water budgets for the area drained by the colorado River in Palo Verde Valley, California, 1981-84, in acre-feet per year

\begin{tabular}{|c|c|c|c|c|}
\hline & 1981 & 1982 & 1983 & 1984 \\
\hline \multicolumn{5}{|l|}{ Inflow: } \\
\hline Surface-water diversion... & 87,300 & 80,900 & 30,300 & 37,700 \\
\hline Effective precipitation... & 380 & 1,900 & 510 & 2,400 \\
\hline Total (rounded)... & 87,700 & 82,800 & 30,800 & 40,100 \\
\hline
\end{tabular}

Outflow:

Surface-water discharge

to Colorado River

from olive Lake drain

(measured)

$$
6,370 \quad 8,810 \quad 7,510 \quad 7,710
$$

Consumptive use by

vegetation.......... $54,900 \quad 51,700 \quad 18,500 \quad 23,100$

Unmeasured ground-water

return flow to the

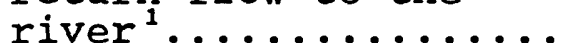

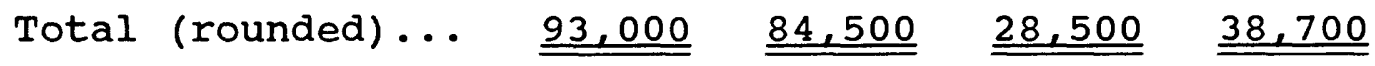

Change in storage: $\quad-5,300 \quad-1,700 \quad 2,300 \quad 1,400$

${ }^{1}$ Unmeasured ground-water return flow to the river was calculated as inflow minus other outflows minus change in storage.

measured components-discharge from drainage ditches to the river and the diversion at Palo Verde Dam.

From year to year, the position of the ground-water divide moves. The total vegetated area east of the divide in 1982 was about 300 acres larger than in 1981; the major difference was that seepage from the river did not occur in 1982. The sensitivity values for ground-water return flow (table 10) increased slightly from 1981 to 1982. The total vegetated area east of the divide in 1983 was, on the average, about 8,200 acres less than in 1981 or 1982. The sensitivity values increased greatly and indicate that ground-water return 
flow is most sensitive to some additional variables the length of canals and change in storage in the area east of the divide. Change in storage for the area drained by the river ranged from 7 to 96 percent of ground-water return flow. In 1984, the total vegetated area east of the divide was about 2,300 acres more than in 1983 and about half the vegetated area in 1981 and 1982 . The sensitivity values correlate more closely with the values and relations stated for 1981 and 1982. The higher sensitivity values in 1983 are related to the overall change in hydrologic conditions in the valley. River stage rose throughout the year. In response to the rise in river stage, the ground-water divide moved to the river in some places and decreased the area drained by the river. The crop types changed because of the PIK program; some fields were fallow and more lower water-use crops were grown in 1983.

\section{DIVERSIONS MINUS RETURN FLOWS}

In a decree by the U.S. Supreme court (1964), the United states is required to account for the consumptive use of lower Colorado River water on a calendar-year basis. The quantity of water diverted from the river at Palo Verde Dam is gaged. Surface-water return flows are computed from measurements and (or) gaging-station records, and ground-water return flows are estimated by using the water-budget method described by Owen-Joyce (1984). The method to estimate consumptive use of river water as diversions minus return flows assumes that the source of all flow in the drainage ditches is the measured diversion at Palo Verde Dam. Agriculture is the primary use of Colorado River water in Palo Verde Valley but some return flows moving through the alluvium are intercepted by domestic pumping and phreatophytes. Quantities of measured diversions, return flows, and consumptive use of river water calculated as diversions minus return flows for 1981 to 1984 are itemized in the following list:

\section{Quantity, in acre-feet}

$\underline{1981} \underline{1982} \quad \underline{1983} \quad \underline{1984}$

$\begin{array}{lrrrr}\begin{array}{l}\text { Surface-water diversion.... } 1,006,000 \\ \text { Surface-water return flow.. }\end{array} \quad 491,500 & 485,200 & 786,700 & 834,900 \\ \text { Ground-water return flow... } & 31,700 & 24,000 & 2,500 & 7,900\end{array}$

Consumptive use

(diversions minus

return flows) ........ $482,800 \quad 432,800 \quad 320,300 \quad 323,900$ 
Consumptive use as diversions minus return flows was consistently lower than consumptive use by vegetation estimated using water budgets during the 4 years studied (fig. 20). The difference between the two estimates varied year to year from 1,200 to 50,400 acre-ft and was greatest during the years of high flow in the river.

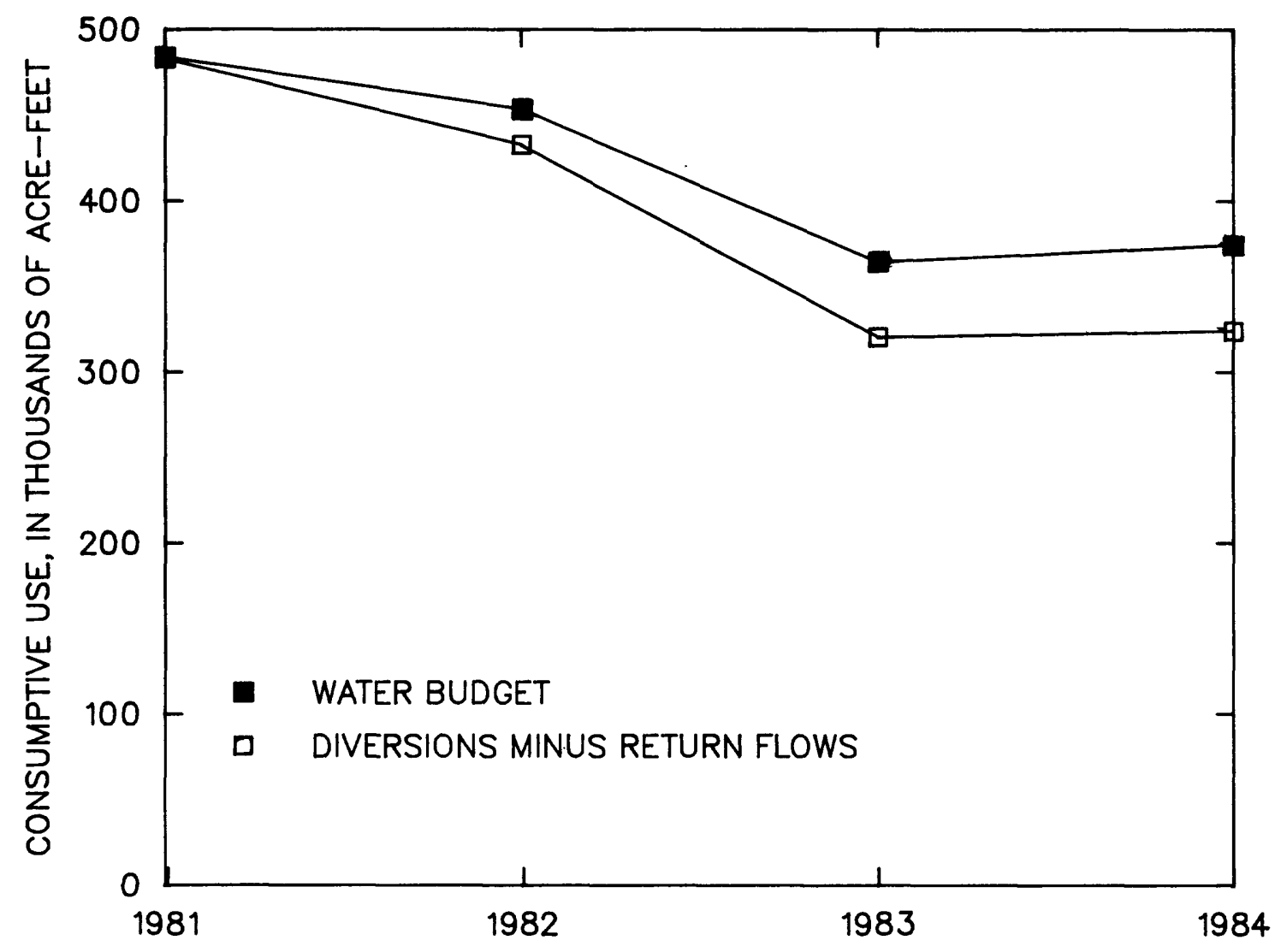

Figure 20.--Comparison of consumptive use by vegetation determined from a water budget and consumptive use of river water determined from diversions minus return flows in Palo Verde Valley, California, 1981-84.

\section{COMPARISON OF CONSUMPTIVE-USE ESTIMATES}

The comparison of consumptive use by vegetation calculated with a water budget to consumptive use of river water calculated as diversions minus return flows helps to show that the method using measured diversions minus return flows does not result in an estimate of the total consumptive use of river water in Palo verde valley. Consumptive use by vegetation calculated with a water budget is not equivalent to consumptive 
use of river water calculated as diversions minus return flows. Consumptive use by vegetation is a major part of the consumptive use of river water, but consumptive use by vegetation on the flood plain does not include the quantity of ground water pumped from the shallow alluvial aquifer or the quantity of the diversion of Colorado River water to Palo Verde Mesa that is consumed. If the pumpage and the total diversion to the mesa are consumed, the water-budget estimate of consumptive use would increase by the sum of the pumpage and the mesa diversion. The difference between the two estimates of consumptive use also would increase by that quantity.

The estimate of consumptive use of Colorado River water using diversions minus return flows is much lower than the estimate of consumptive use by vegetation. The differences are greatest during years of high flow in the river, suggesting a connection to the increase in river seepage, which moves through the alluvium and into the drainage ditches. Other sources of water to the drainage ditches are tributary runoff and ground-water inflows, which may account for the differences in years when flow in the river is regulated to meet downstream requirements.

Consumptive use of Colorado River water is underestimated when calculated as measured diversions minus return flows because this method does not include the effects caused by variations in precipitation, tributary inflow, or river stage. In years of above-average precipitation that generate aboveaverage tributary runoff, the tributary runoff flows into the drainage ditches and is measured and credited as surface-water return flows. Tributary ground-water inflow also is captured in drainage ditches and measured as surface-water return flows. Changes in river stage affect the quantity of water moving through the aquifer that originates as seepage from the river. During periods of high river stage, larger quantities of river seepage result in increased bank storage, increased captured river seepage in the drainage ditches, and a backwater effect on irrigation return flow in the aquifer along drainage ditches. Captured river seepage in the drainage ditches is not accounted for in the diversion of Colorado River water but is measured and credited as surface-water return flows from that diversion. overestimating surface-water return flows results in underestimating the consumptive use of river water. The response time to changes in river stage that occur late in the year may be significant in delaying part of the effects into the next calendar year. These changes in ground-water storage are not accounted for in the calculation of diversions minus return flows.

\section{SUMMARY}

Palo Verde valley is on the flood plain of the colorado River and is used mostly for agriculture. The valley 
is underlain by a shallow alluvial aquifer that is in hydraulic connection with the Colorado River and a network of drainage ditches. Precipitation is insufficient for growing crops. Palo Verde Dam diverts water from the Colorado River into a system of irrigation canals. Drainage ditches are used to reduce damage to crops from shallow ground water. Application of irrigation water and the network of drainage ditches control the direction of ground-water movement and the saturated thickness in the shallow aquifer. The diversion at Palo verde Dam and the surface-water return flows to the river are measured. The valley is divided into two ground-water drainage areas by a ground-water divide, which is determined from contours of annual average water-table altitudes. Areas east of the divide drain to the colorado River and areas west of the divide drain to drainage ditches. The location of the ground-water divide shifts from year to year and is controlled mainly by river stage and the amount of irrigation, both of which change the location of gaining and losing reaches along the river.

Annual water budgets were used to determine consumptive use by vegetation and ground-water return flow from 1981 to 1984. Consumptive use by vegetation in Palo verde Valley was 484,000 acre-ft in 1981, 453,600 acre-ft in 1982, 364,400 acre-ft in 1983, and 374,300 acre-ft in 1984 . sensitivity analyses of the primary variables used in the computation of consumptive use by vegetation show that variations in computed consumptive use are most sensitive to two measured components - the diversion at Palo Verde Dam and the discharge from drainage ditches to the river. The movement of the ground-water divide and the changes in ground-water storage do not significantly affect the computation of consumptive use by vegetation. Ground-water return flow was estimated to be 31,700 acre-ft in 1981, 24,000 acre-ft in 1982, 2,500 acre-ft in 1983, and 7,900 acre-ft in 1984. Sensitivity analyses indicate that variations in computed ground-water return flow are most sensitive to discharge from drainage ditches to the river; various irrigation requirements, particularly for alfalfa; various crop areas, particularly those of alfalfa; and the diversion at Palo verde Dam. During years when flow in the river increases, variations in computed ground-water return flow are sensitive also to change in ground-water storage and the length of canals in the area drained by the river. Year-to-year variations in the ground-water return flow sensitivity of the primary variables indicate that (1) rising river stage within a year causes the ground-water divide to move toward the river and, thus decreases the area drained by the river and (2) changes in crop types from year to year, especially when fields are left fallow, cause the largest changes in the ground-water return flow sensitivity values for all the variables.

Maps that show change in annual average ground-water level were used to calculate change in ground-water storage. Water-level changes were caused by change in river stage adjacent to the river and variations in the amounts of irrigation in the area west of the easternmost drainage ditch. 
From 1981 to 1984 , local changes in water levels ranged from -6.08 to $5.06 \mathrm{ft}$, and average water-level changes ranged from -0.37 to $0.33 \mathrm{ft}$. Annual change in ground-water storage from 1981 to 1984 ranged from $-12,600$ to 11,600 acre-ft and was 1 to 3 percent of consumptive use for each year. The change in storage for the area drained by the river ranged from $-5,300$ to 2,300 acre-ft and was 7 to 96 percent of unmeasured ground-water return flow. Change in ground-water storage can be a significant component in a water budget to estimate ground-water return flow.

Estimates of average consumptive use per unit vegetated area for the area drained by the drainage ditches were within 1 percent of the consumptive use per unit vegetated area for Palo Verde Valley. Therefore, consumptive use per unit area for the area drained by drainage ditches can be used as an estimate of the consumptive use per unit area for Palo Verde Valley. Consumptive use of Colorado River water calculated by diversions minus return flows was consistently less than consumptive use by vegetation determined by the water-budget method because the effects caused by variations in precipitation, tributary inflow, and river stage are not considered in the calculation of diversions minus return flows. Water-budget estimates of consumptive use account for changes in these components and include change in ground-water storage.

\section{SELECTED REFERENCES}

Bookman-Edmonston Engineering, Inc., 1976, Reduction of salt loading to the Colorado River from Palo Verde Irrigation District: Glendale, California, Report prepared for U.S. Bureau of Reclamation, $75 \mathrm{p}$.

Boyle Engineering corporation, 1976, salinity control and irrigation system analysis, colorado River Indian Reservation, Yuma county, Arizona: Phoenix, Report prepared for U.S. Bureau of Reclamation, 267 p.

California Department of Water Resources, 1981, Index to sources of hydrologic data: California Department of Water Resources Bulletin 230-81, $696 \mathrm{p}$.

Metzger, D. G., and Loeltz, O. J., 1973, Geohydrology of the Needles area, Arizona, California, and Neváda: U.S. Geological Survey Professional Paper 486-J, $54 \mathrm{p}$.

Metzger, D. G., Loeltz, O. J., and Irelan, Burdge, 1973, Geohydrology of the Parker-Blythe-Cibola area, Arizona and California: U.S. Geological Survey Professional Paper 486-G, $130 \mathrm{p}$. 
National Climatic Data Center, 1980-84, Climatological Data California: U.S. Department of Commerce (published monthly).

Owen-Joyce, S. J., 1984, A method for estimating ground-water return flow to the colorado River in the Palo Verde-Cibola area, California and Arizona: U.S. Geological Survey Water-Resources Investigations Report $84-4236,48 \mathrm{p}$.

Raymond, L. H., and owen-Joyce, S. J ., 1986, Estimates of consumptive use and evapotranspiration in Palo verde Valley, 1981 and 1983 , in Johnson, A. I., and Rango, A., eds., Remote Sensing Applications for Consumptive Use (Evapotranspiration): American Water Resources Association Monograph Series No. 6, p. 25-34.

1987, Comparison of estimates of evapotranspiration and consumptive use in Palo verde Valley, California: U.S. Geological Survey water-Resources Investigations Report 87-4071, $27 \mathrm{p}$.

Raymond, L. H., and Rezin, K. V., 1986, Evapotranspiration estimates using remote-sensing data, Parker and Palo Verde Valleys, Arizona and California: U.S. Geological Survey Open-File Report 86-67, $33 \mathrm{p}$.

U.S. Supreme Court, 1964, state of Arizona, plaintiff v. State of California, et al., defendants: Decree--March 9, 1964 , no. 8, original, $14 \mathrm{p}$. 